\title{
Does public sector efficiency matter? Revisiting the relation between fiscal size and economic growth in a world sample
}

\author{
Konstantinos Angelopoulos \\ University of Glasgow \\ Apostolis Philippopoulos \\ Athens University of Economics \& Business, University of Glasgow, and CESifo \\ Efthymios Tsionas \\ Athens University of Economics \& Business
}

January 2008

\begin{abstract}
This paper revisits the relationship between fiscal size and economic growth. Our work differs from the empirical growth literature because this relationship depends explicitly on the efficiency of the public sector. We use a sample of 64 countries, both developed and developing, in four 5-year time-periods over 1980-2000. Building on the work of Afonso, Schuknecht and Tanzi (2005), we construct a measure of public sector efficiency in each country and each time-period by calculating an output-to-input ratio. In addition, we get an estimate of technical efficiency of public spending for 52 countries for the time-period 1995-2000 by employing a stochastic frontier analysis. Using these two measures, we find evidence of a non-monotonic relation between fiscal size and economic growth that depends critically on the size-efficiency mix.
\end{abstract}

Keywords: Fiscal policy, government efficiency, growth.

JEL classification: H1, E6, 04.

Corresponding author: Apostolis Philippopoulos, Department of Economics, Athens University of Economics \& Business, 76 Patission Street, Athens 10434, Greece. Tel. +30-210-8203357. Fax: +30-210-8203301. Email: aphil@aueb.gr

Acknowledgements: We thank S. Kalyvitis, P. Kammas, M. Katsimi, J. Malley, M. Ntelis, H. Park, E. Tzavalis and seminar participants at the University of Stirling and the 2007 Scottish Economics Society Conference for discussions and comments. Any errors are ours. The first coauthor is grateful to the "Foundation Propondis" for their support. 


\section{Introduction}

The relationship between government size and economic growth is not expected to be monotonic. On one hand, governments provide public goods and services and correct market failures. On the other hand, policy intervention generates its own distortions, as it requires taxes and distorts incentives. There is thus a tradeoff depending on the size-efficiency mix of the public sector. By efficiency, we mean the ability of the government to transform its revenues into public goods and services that benefit the economy and promote growth. After a critically large size, or a critically low efficiency, the costs of a larger public sector outweigh the benefits. ${ }^{1}$

This paper revisits the relation between fiscal size and economic growth. Our work differs from the empirical growth literature because this relation depends explicitly on the efficiency of the public sector. We use a sample of 64 countries, both developed and developing, in four 5-year periods over $1980-2000$.

To obtain a measure of government efficiency, we follow the methodology of Afonso, Schuknecht and Tanzi (2005) for the OECD and construct measures of public sector efficiency (PSE). This index measures the efficiency of public sector in reaching a range of objectives of government intervention. It is basically the ratio of performance indicators (output) to a measure of public expenditure related to those indicators (input), based on the assumption that the input is used to achieve that output. We construct such indexes of public sector efficiency for four policy areas: administration, stabilization, infrastructure and education. In addition to this measure, focusing on 52 countries for the sub-period 1995-2000 during which more data are available, we also obtain an estimate of the so-called technical efficiency (TE) of the public sector by applying a stochastic production frontier analysis (see e.g. Kumbhakar and Lovell, 2000, and Greene, 2005). The ranking of countries according to the TE measure does not differ substantially from that implied by the PSE measure.

We then incorporate these two measures (PSE or TE) into a simple econometric model in which the size-growth relationship is non-monotonic depending on the size-efficiency mix. This novel feature is included into an otherwise standard growth regression (see e.g. Barro and Sala-iMartin, 2004, chapter 12).

Our main finding is that, when the fiscal size is measured by the government consumption share in GDP, the size-efficiency mix is significant in explaining the size-growth relationship. The latter is indeed non-monotonic as discussed above. This result holds for both efficiency measures

\footnotetext{
${ }^{1}$ A simple and popular conceptual framework is provided by Barro’s (1990) model, where there is a trade-off between growth-promoting public goods and the distorting taxes required to finance them. When the government size and its associated tax burden are high (resp. small) relative to the productivity of public sector, a larger size is bad (resp. good) for growth. See also Hillman (2003) and Mueller (2003) on the market failures vs policy distortions trade-off.
} 
constructed and is robust to a number of changes in the econometric specification, as well as to dividing the world sample into two sub-samples consisting of "high-income” and "developing" countries. Among other things, the model provides an endogenously determined efficiency threshold below (resp. above) which the size-growth relationship is negative (resp. positive). In general, this relationship is found to be negative in most countries and time periods. When we use, for instance, the PSE as a measure of efficiency in our world sample for all four 5-year periods, our estimates imply that only in 34 out of 159 observations (different countries in different periods) the size-growth relationship is positive. ${ }^{2}$

Our results imply that what really matters to growth is not the government size per se, but the size-efficiency mix. They can also help to explain why the evidence on the growth effects of the overall fiscal size has so far been mixed (see e.g. Levine and Renelt, 1992, Tanzi and Zee, 1997, Gemmel and Kneller, 2001, and Mueller, 2003, chapter 22). Essentially, our results suggest that it is difficult to obtain a "robust" effect of the overall fiscal size on economic growth when important elements that shape the size-growth relationship (in our case, the efficiency of the public sector) are omitted from the analysis. ${ }^{3}$ In sum, as Levine and Renelt (1992, p. 951) point out, "using simple expenditure data without accounting for government efficiency may yield inaccurate measures of the actual delivery of public services".

The rest of the paper is as follows. Section 2 develops measures of government efficiency. Section 3 studies the growth effects of the size-efficiency mix. Conclusions are in Section 4.

\section{Measures of government efficiency}

In this section, we present two measures of government efficiency.

\subsection{Public sector efficiency}

Following Afonso et al. (2005, 2006), we construct sub-indices of relative Public Sector Efficiency (PSE) in certain policy areas in each country and each time period, and then take the average of these sub-indices to obtain an index of aggregate government efficiency in each country and each time period.

\footnotetext{
${ }^{2}$ Regarding the causal effect of fiscal size on economic growth, a concern has been the potential endogeneity of fiscal size. The literature so far has not provided a "credible” identification of fiscal size in growth regressions (see e.g. Agell et al., 2006). Although the aim of our paper is not to resolve the causality issue, we also provide some evidence that it can be easier to find a credible identification of the size-efficiency mix, rather than of size alone, in growth regressions.

${ }^{3}$ An additional potential explanation that has received a lot of empirical support is that the overall size of government cannot capture the different implications of different government activities. As has been shown (see e.g. Devarajan et al., 1996, Kneller et al., 1999, and Angelopoulos et al., 2007), the growth effects of the different components of government expenditure, as well as of the various types of tax instruments, are not the same. See also Angelopoulos and Philippopoulos (2007) for a single country, time-series study that also supports the result that both the composition and efficiency of the government matter.
} 
Afonso et al. have constructed PSEs for seven policy areas for OECD countries over the eighties and nineties. Here, we focus on four policy areas (education, administration, infrastructure and stabilization) for 64 countries, both industrialized and developing, and four 5-year time-periods, over 1980-2000 (obviously, due to data availability, there is a trade-off between the number of countries and the number of policy areas). ${ }^{4}$ We keep only those observations for which indexes of government efficiency in all four areas are available.

Since the methodology is in Afonso et al. (2005, 2006), here we only discuss the basic insight and point out where we differ. The basic insight of this methodology is to compare the performance of government in certain areas of economic activity (where these areas are influenced directly by government intervention) to the associated expenditure that the government allocates to achieve this particular performance. Thus, to construct a PSE index, we need a measure of Public Sector Performance (PSP) and a measure of the associated Public Sector Expenditure (PEX) for each country in each policy area and each time-period. Then, the PSE will be the ratio of PSP to PEX. More details about the construction of PSP and PSE indexes in each policy area are in our Appendix.

To make these PSP and PEX measures (expressed in different units of measurement) comparable across countries, we follow Afonso et al. by expressing each country's PSP and PEX relative to the average PSP and PEX of all countries in each period, and this is done for all periods and indexes. In other words, each country's PSP and PEX are expressed as percentages of the respective average (normalized to be 1), and in turn the PSE is obtained as the ratio of these relative PSP and PEX. ${ }^{5}$ Therefore, the resulting PSE is an index that measures the efficiency of a country's government relative to governments in other countries in each period in a particular policy area. The larger the value, the more efficient the country's government is. This is the notion of relative efficiency in Afonso et al.

Table A.1 in the Appendix reports the relative PSPs, and the resulting PSEs, in the four policy areas for the countries and the time-periods that data are available. The order of countries is alphabetical. The second-from-the-end column in Table A.1 reports the (relative) aggregate efficiency of a country's government obtained as the average of the four (relative) sub-indices. As expected, high-income OECD countries get on average better scores, although the public sectors in economies like Korea, Thailand or Malaysia appear to be particularly efficient. The most efficient governments during 1995-2000 are those of Korea (2.221), Canada (2.039), the USA (1.938) and

\footnotetext{
${ }^{4}$ Greene (2005) has measured the efficiency of public spending in developing countries focusing on the areas of health and education. Afonso et al. (2006) have also constructed measures of public sector efficiency for a group of 24 uppermiddle income countries for the late nineties.

${ }^{5}$ Since the averages of PSP and PEX are both normalized to be 1 , the resulting PSE has an average around 1 (specifically, the PSEs in education and stabilization have an average of about 1.1, whereas the PSEs in infrastructure and administration have an average of about 1.25).
} 
Switzerland (1.813) that are twice as efficient as the average countries, e.g. United Kingdom or France. At the bottom end, Namibia (0.483), Nicaragua (0.447) and Yemen (0.35) score about half of the average score. ${ }^{6}$

Of course, we have to be cautious with these estimates. For instance, in rich countries, like Finland or Sweden, the cost of resources used for providing public education or capital is higher than in say Uruguay or Lebanon, and this may result in an overestimation of relative efficiency in the latter group of countries. In addition, government performance in a certain policy area may be overestimated when private resources are used to complement government policy; this is especially the case of education in many countries (e.g. Greece).

In sum, the main advantage of the above output-to-input approach is its simplicity and logical coherence, which allow a meaningful comparison across countries. Its main weakness is that several assumptions have to be made to calculate such a composite index (for a critical assessment of different methodologies and measures of public sector efficiency, see e.g. Afonso et al., 2005 and 2006, as well as the special issue of European Economy, no. 3, 2004, on "Public finances in EMU 2004”).

\subsection{A stochastic production frontier methodology}

As an alternative approach to measuring government efficiency, we estimate a stochastic production frontier for the public sector and then obtain an estimate of the so-called Technical Efficiency (TE ) of this sector. For a review of this methodology, see Kumbhakar and Lovell (2000).

Our stochastic frontier model is of the form:

$\ln y_{i}=\beta_{0}+\beta_{1} \ln x_{i}+v_{i}-u_{i}$

where $y_{i}$ is a measure of public sector output in country $i, x_{i}$ is a measure of public sector input, $u_{i}$ is the nonnegative technical inefficiency component of the error term, and $v_{i}$ is the noise component assumed to be distributed normally and independently of $u_{i}$. Both error components are assumed to be independent of the regressors.

\footnotetext{
${ }^{6}$ Two countries score suspiciously high in this Table. Paraguay, which seems to be the most efficient country in the world, and Argentina, which seems to be the second most efficient country in the last time-period. Regarding Paraguay, this result is driven by a very high score in the variable Electric Power Transmission and Distribution Losses (see the Appendix), which results in a very high PSP in infrastructure. This score may reflect measurement errors or unusual circumstances, so we drop Paraguay from our regressions in the next section. Regarding Argentina, the high efficiency score for 1995-2000 is probably due to the extended stabilization program implemented by the country in this period. We also choose not to include Argentina in our analysis in the next section. We report, however, that including these two countries does not have a significant effect on the econometric results presented later.
} 
After estimating equation (1) by maximum likelihood, a measure of technical efficiency for each country $i\left(T E_{i}\right)$ is defined as:

$$
T E_{i}=E\left[\exp \left\{-u_{i}\right\} / \varepsilon_{i}\right]
$$

where $\varepsilon_{i}=v_{i}-u_{i}$ (see Kumbhakar and Lovell, 2000, chapter 3, for details). This efficiency score is bounded between zero and one.

To apply the above, we need to measure public sector outputs and inputs $\left(y_{i}\right.$ and $x_{i}$, respectively). We use the average of the PSP indices as a measure of $y_{i}$. As a measure of $x_{i}$, we use Total Government Expenditure (as a share of GDP) which is available from the World Development Indicators. We estimate (1)-(2) under the assumption that $u_{i}$ is characterized by a nonnegative half-normal distribution (we have also examined the case where $u_{i}$ is assumed to follow a truncated normal distribution but, since this gives very similar results, we discuss only the nonnegative half-normal case).

Results for each country's technical government efficiency $\left(T E_{i}\right)$ during the 1995-2000 sub-period (where we again look at a 5-year period average, as we did with the PSE measure above) are reported in Table A.2. ${ }^{7}$ The ranking results look sensible again. In this cross-section world sample during 1995-2000, Switzerland's government scores the best being followed by Sweden and Finland. Again, as probably expected, governments in OECD countries are more efficient than those in developing countries, although public sectors in fast-growing economies like Thailand, Malaysia, Cyprus and especially Korea get high scores. Algeria, Nicaragua and Yemen have now the least efficient governments. Therefore, the ranking of countries using the PSE measure does not differ substantially from that using the TE measure (recall that this refers to the 1995-2000 period during which both measures are available) with the correlation coefficient being 0.75 .

In this sample, an LR test of the null that $\sigma_{u}^{2}=0$ gives a value of 5.64, which rejects the null (the respective p-value of the test is 0.009). ${ }^{8}$ This implies that government technical efficiency differs significantly across countries during 1995-2000. We report that we have also estimated government TE during the three time-periods before 1995 (i.e. the three 5-year periods between 1980 and 1995). However, there are significantly less data available for these earlier years

\footnotetext{
${ }^{7}$ To examine whether the $T E_{i}$ estimates in Table A.2 are not biased due to heteroskedasticity in either $v_{i}$ or $u_{i}$ (see Kumbhakar and Lovell, 2000), we have tested whether the variance functions of $v_{i}$ or $u_{i}$ depend (linearly) on govexp. Since this is rejected, we can have some faith in the homoskedasticity assumption.

${ }^{8}$ The limiting distribution of the LR test statistic is a mixture of a chi-square with zero degrees of freedom, i.e. a point mass at zero, and a chi-square with 1 degree of freedom (see e.g. Kumbhakar and Lovell, 2000). The p-value of the test reported here takes this into account.
} 
(especially in the eighties when the sample size drops to around 25-30, i.e. it mainly consists of the OECD countries). Not surprisingly, we have not been able to reject the null $\sigma_{u}^{2}=0$ for any of these early periods. Hence, concerning the TE measure, we concentrate on the 1995-2000 period.

In sum, the $T E$ measure has obvious advantages but, on the other hand, it depends on the assumptions made about the error term. The assumption that government expenditure is uncorrelated with the error term may be strong when governments respond to negative shocks by increasing their expenditures. In any case, the $T E$ measure of government efficiency provides a useful alternative measure also used below to check the importance of the size-efficiency mix.

\section{The size-efficiency nexus matters to growth}

This section tests whether there is a non-monotonic relationship between government size and economic growth with this relationship driven by the size-efficiency mix.

\subsection{Econometric model}

We use the above constructed measures of government efficiency (PSE or TE) in a growth regression of the following form (see Dutt and Mitra, 2002, for a similar specification in a trade policy context):

growth $_{i t}=\alpha_{0}+\alpha_{1}$ size $_{i t}+\alpha_{2}$ size $_{i t} * e f f_{i t}+X_{i t} \beta+\varepsilon_{i t}$

where growth $_{i t}$ is the growth rate of country $i$ at time $t$, size $e_{i t}$ is a measure of government size, eff $f_{\text {it }}$ is a measure of government efficiency (PSE or TE) and $X_{i t}$ includes control variables usually included in growth regressions (see below).

The partial derivative with respect to size $_{i t}$ is simply:

$\frac{\partial \text { growth }_{i t}}{\partial \operatorname{size}_{i t}}=\alpha_{1}+\alpha_{2} e_{\text {eff }}$

where we expect $\alpha_{2}$ to be positive in the sense that the more efficient the public sector, the larger the positive effect of government on growth. We also expect $\alpha_{1}$ to be negative to catch the adverse effects of government size on growth.

As long as the estimated coefficients $\alpha_{1}$ and $\alpha_{2}$ in (3) are statistically significant and have the right signs, so that the size-efficiency nexus matters to growth, the above specification can also 
give an estimate of a (common to all countries) critical level of efficiency, eff ${ }^{*}$, where eff ${ }^{*} \equiv-\left(\alpha_{1} / \alpha_{2}\right)>0$ makes the partial in (4) equal to zero. When an individual country's efficiency, eff ${ }_{i t}$, is higher (resp. lower) than $e f f^{*}$, the positive (resp. negative) effects dominate and the country is placed on the positively (resp. negatively) sloped part of the size-growth curve; this, of course, requires eff ${ }^{*}$ to lie within the range of values of $e f f_{i t}$ in the data. Note that (3)-(4) imply that the growth effects of fiscal size can differ among countries and time-periods. ${ }^{9}$

\subsection{Data and variables used in the regressions}

For the eff variable, we use the two measures of government efficiency (TE and PSE) constructed in section 2 above. The rest of the variables are as in most of the literature. We work with 5-year period averages as we did with our eff measures (5-year periods are also used in the growth literature, especially the literature on the growth effects of fiscal policy, see e.g. Folster and Henrekson, 2001, and Kneller et al, 1999). The main datasets used are the Penn World Tables (PWT) version 6.1 (see Heston et al., 2002) and the World Development Indicators (WDI) developed by the World Bank.

Our dependent variable, the growth rate of per capita GDP, is from the PWT. In particular, the PWT dataset provides us with the real GDP per capita in constant prices, which is then used to obtain the five-year average of annual growth rates (denoted as growth in our regressions). The PWT also provides us with consumption of the general government as a share of GDP in constant prices, which is averaged over 5-year periods to give a variable denoted as govshare in our regressions. This will be our primary measure of government size. ${ }^{10}$ An alternative measure of government size, which is also used below, is total expenditures of the central government as a share of GDP (denoted as govexp in our regressions and obtained from WDI). This variable includes transfers and interest payments on public debt, in addition to government consumption (note that to avoid double counting, we do not include government investment in our govexp measure, as government investment is included in the investment share in GDP used as a separate regressor (see below).

\footnotetext{
${ }^{9}$ We have also examined a specification like growth ${ }_{i t}=\alpha_{0}+\alpha_{11} \operatorname{size}_{i t}+\alpha_{12} \operatorname{size}_{i t}{ }^{2}+X_{i t} \beta+\varepsilon_{i t}$, which gives a partial as a function of size, so that an "optimal" size can be calculated given the estimated coefficients irrespectively of efficiency. We report that estimation of this equation does not give meaningful results (coefficients are not significant and in some regressions they have wrong signs).

${ }^{10}$ This is the general government consumption component of GDP. It does not include public investment, interest payments, subsidies and other transfers. Public investment is included in PWT in the variable "investment share in GDP” (see below). Note however that a large part of government spending on goods and services, included in govshare, has investment features (e.g. salaries of teachers, professors and doctors and spending on police or the judiciary system). The variable govshare is closer to what Tanzi and Schuknecht (2000) refer to as a measure of "real government expenditure”.
} 
Concerning the above two measures of fiscal size, an advantage of govshare over govexp is that it refers to the general government and can thus capture better the full trust of fiscal size on economic growth; moreover, it is PPP adjusted and therefore more suitable for international comparisons. The advantage of govexp, on the other hand, is that it allows us to examine whether including more types of government expenditure (at the disadvantage of using data at the central level only) gives different results regarding the effect of fiscal size on growth. Ideally, we would like to have a measure of general government spending for all types of government expenditure, but unfortunately, such a measure does not, as far as we know, exist for all the countries and time periods in our world sample. Finally, the fiscal size of government can be also measured by tax revenue or the budget balance, both as shares of GDP (see e.g. Tanzi and Zee, 1997, and Persson and Tabellini, 2003); see below in subsection 3.4 for details. ${ }^{11}$

In our choice of the control variables included in $X$ in equation (3) above, we will follow most of the literature (see e.g. Barro and Sala-i-Martin, 2004, chapter 12, and the review papers mentioned above). Thus, we use the logarithm of the initial level of GDP per capita (denoted as $\operatorname{lgdp}$ ), obtained from PWT, to control for convergence effects; the initial (or the value closest to the beginning of the period) secondary school enrolment rate (denoted as enrol), obtained from WDI, to proxy for human capital; ${ }^{12}$ the investment share of GDP (denoted as investment), obtained from PWT and averaged over the 5-year period; the logarithm of the fertility ratio (denoted as fertility), obtained from WDI; a measure of openness (denoted as openness), obtained from PWT and defined as the sum of exports and imports over GDP. ${ }^{13}$ Finally, we include in our regressions time dummies, as well as regional dummies for countries in Sub-Saharan Africa, East Asia, Latin America and the economies in transition.

\subsection{Basic results}

Results using the PSE measure of efficiency for the sample of 64 countries over 1980-2000 are presented in Table 1. We report standard errors obtained under the assumption of spherical errors and standard errors that are robust to arbitrary heteroskedasticity and arbitrary intra-country serial

\footnotetext{
${ }^{11}$ The tax revenue-to-GDP ratio is generally not preferred to fiscal spending measures, mainly because of tax evasion problems (see e.g. Tanzi and Zee, 1997). The same can be said about the budget-to-GDP ratio since it includes tax revenue.

${ }^{12}$ A better proxy for human capital could be a measure of the average years of schooling (see e.g. Barro and Sala-iMartin, 2004). However, such measures are not available for all the countries in our sample and we do not want to restrict our sample for any other reasons than the requirements for the efficiency measure. Hence, we use the enrol variable, also used by Levine and Renelt (1992).

${ }^{13}$ We have also used the average annual growth rate of the labour force, obtained from the WDI, in the growth regressions, but it is always insignificant.
} 
correlation (see e.g. Wooldridge, 2002). The first three columns report estimates when using govshare as a measure of fiscal size and the last three when using govexp. ${ }^{14}$

\section{Table 1 around here}

In column 1 of Table 1, we start with a standard growth regression: the coefficient of govshare is significantly negative. In column 2, we add the PSE measure of government efficiency, which is positive but marginally significant, while the coefficient of govshare remains significantly negative. To examine whether it is government efficiency that shapes the size-growth relationship, we move to column 3, which presents results for our key equation (3) above. ${ }^{15}$ Both estimates of govshare and govshare*eff are significant with the expected sign (negative and positive respectively), indicating a heterogeneous across countries size-growth relationship depending on government efficiency. Actually, the estimates imply a threshold of eff ${ }^{*}=1.358$, which means that only in 34 out of 159 observations (different countries in different time periods), the size-growth relationship is positive.

The estimated coefficients $\alpha_{1}$ and $\alpha_{2}$ also allow us to calculate the growth effect of fiscal size in each country and each time period, as implied by equation (4). Results are reported in the last column of Table A.1. As can be seen, the estimated effect differs substantially across countries. There is a small group of countries where public sectors are efficient meaning a positive growth effect from fiscal size. This group includes Canada, Japan, Korea and Switzerland in all time periods we have data for; and Australia, Finland and the USA in most time periods (here we report those countries with more than one observation/time period; see Table A.1 for all countries). However, for most countries and time periods, this effect is negative. Therefore, the general picture that emerges is that fiscal sizes have grown too much - relative to public sector efficiency - in the last decades. This finding is similar to the arguments made in e.g. Gwartney et al. (1998) and Tanzi and Schuknecht (2000) although these papers do not take account of efficiency explicitly.

Regarding the control variables that enter significantly, $\lg d p$ is negative, implying (conditional) convergence, while investment and openness are positive. The effect of fertility is negative (this is as in Barro and Sala-i-Martin, 2004, chapter 12) but not robustly significant. The effect of enrolment is positive but not significant. Regarding the regional dummies, those for the economies in transition are significantly negative, while those for Latin American countries are

\footnotetext{
${ }^{14}$ We do not include a dummy for each country (and thus we do not estimate fixed effects regressions) as this would result in losing all cross-country variation. This is important because the measure of efficiency developed here is a relative one across countries. It would make little sense to use this variation to explain differences within countries only.
} 
negative but not significant when we use robust standard errors. An interesting result is the negative dummy for East Asian countries, as this variable usually has a positive effect in similar regressions (see e.g. Barro and Sala-i-Martin, 2004, chapter 12). However, East Asian countries, in general, are ranked highly in our efficiency measures (see Table A.1), so that a large part of the positive regional effect has been already controlled for by our fiscal measure.

The results are less clear when we use the other widely used measure of fiscal size, govexp (see the last three columns in Table 1). The coefficient of govexp is negative but not robustly so (see column 5 that includes pse). More importantly, in column 6, there is no significant evidence of a non-linear relationship like the one found in column 3; namely, the coefficient of govexp*pse is not significant (although it has the right sign). Recall that the key difference between govshare and govexp is that the latter includes redistributive transfers and interest payments on public debt. Both items (i.e. transfers and interest payments) do not involve a direct use of real resources by the state sector (recall the economy's resource constraint). We thus do not find it surprising that govexp does not give as clear results as govshare. In a sense, these new results indicate that both the sizeefficiency mix and the composition of government expenditure matter to growth. ${ }^{16}$

\subsection{Robustness of basic results}

We now examine the robustness of the basic results above by extending the empirical specification in two dimensions. First, we test whether our results - regarding the importance of the sizeefficiency mix on growth - are sensitive to the financing assumption of government spending (see e.g. Miller and Russek, 1997, and Kneller et al., 1999). Given that we do not have detailed tax and spending data for all the countries and time periods in our sample, we use a general form of government budget that equates aggregate spending to tax revenue and deficit (see e.g. Miller and Russek, 1997). In principle, in the absence of Ricardian equivalence, the effect of spending on growth can be different depending on whether higher spending is financed by more tax revenues or by a larger budget deficit (higher debt). If, for instance, we include a measure of taxation, together with spending, in a growth regression, we would expect the effect of the tax measure to be negative

\footnotetext{
${ }^{15}$ We do not include eff together with size ${ }^{*}$ eff in the same regression, as they are highly correlated and as a result both eff and size* eff become insignificant. In this specification, the growth effect of government efficiency takes place only via government size, assuming that efficiency is independent of size.

${ }^{16}$ We have also used another potential measure of the extent of government involvement in the economy, the so-called Economic Freedom index as developed by the Fraser Institute (see e.g. Gwartney et al., 2006). The Economic Freedom (EF) index is a rather general measure of government involvement than includes the size of government; the degree of regulation of credit, labor and business by the government; the legal structure; the security of property rights; the freedom to trade; etc. We report that, when we use the EF index as a measure of fiscal size in our regressions for the world sample (i.e. instead of govshare and govexp), then (a) it has a negative growth effect (see also De Haan et al., 2006) although this effect is not always significant (b) the estimated $\alpha_{2}$ is not significant in equations (3)-(4) above. We believe this is not surprising given that this index contains more variables than the size of the government, while equations like (3) test whether the growth effect of size depends on the size-efficiency mix. Besides, the EF index may be correlated with government efficiency.
} 
capturing the adverse implications of a larger fiscal size, whereas the effect of the spending measure to be positive capturing the positive effects of e.g. more public good provision. It is therefore interesting to see whether our results are robust to the inclusion of a finance instrument (obviously, because of multi-collinearity problems, we cannot include both tax revenues and public deficits in the regressions).

For our sample, we obtain data for tax revenues, as a share of GDP, from the WDI database (we denote the respective measure, which is again expressed in 5-year period averages, as tax). We then rerun the basic regressions of Table 1 by including tax as an additional explanatory variable. Results for the main variables are shown in Table 2 (since the estimates for the control variables are not generally affected, we do not include them in Table 2 to save on space - these results are available upon request). As can be seen, the results of Table 1 remain essentially unchanged when we include tax, which, itself, is not significant. We report that these results again do not change if we use deficits instead of taxes. ${ }^{17}$

Tables 2 and 3 around here

Second, we also test whether the inclusion of lagged growth rates changes our results. Although our basic specification (see Table 1) is common in the empirical growth-policy literature working with 5-year averages (see e.g. Kneller et al., 1999, and Folster and Henrekson, 2001), dynamic effects from past growth may persist even after five years. Therefore, we now examine whether the size-efficiency mix retains its significance in explaining economic growth, even after controlling for lagged growth rates (see also Miller and Russek, 1997). Results obtained from including the lagged-once growth rate (denoted as grolag in our regressions) as an explanatory variable in the regressions of Table 1 are reported in Table 3 (again, we present results for the main variables only to save on space). Note that the sample size drops from 159 to 98 observations (there are now 46 instead of 62 countries). The lagged-once growth rate is generally significant, but the results for the main variables of interest are not qualitatively affected. Actually, in column (3), where we present our key results by using govshare, grolag is not found to be significant.

\footnotetext{
${ }^{17}$ Notice, when we compare Tables 1 and 2, that the inclusion of tax does not alter the negative effects of govshare and govexp in columns (1) and (4) respectively. Thus, the effect of government size itself, as measured by govshare or govexp, remains negative even if we add a measure of the tax burden, tax. This is probably because tax revenues, as an ex post measure, is not an ideal proxy for the distortions imposed by the tax system; higher tax revenue may e.g. reflect less tax evasion and better institutions (see Tanzi and Zee, 1997 and Angelopoulos et al., 2007, for discussion and references). Thus, the basic size-efficiency specification in Table 1 appears to be good enough to capture the trade-offs in fiscal policy at least in our sample. In other words, to the extent that we allow the effect of the fiscal size to depend on the size-efficiency mix, we view our basic specification as an alternative to including both spending (see positive effects) and taxation (see negative effects) to capture the trade-off in fiscal policy.
} 
Finally, in Table 4, we present results for the main variables by including both grolag and tax in our regressions. As can be seen, the previous results and analysis remain robust to this specification as well.

\section{Table 4 around here}

\subsection{High-income and developing countries}

So far - although we allowed for the effect of fiscal size to differ across countries depending on the efficiency of the public sector in each country - we have studied rich and developing countries jointly in a single sample. We now divide countries into two subgroups to study whether the sizeefficiency mix matters differently in high income and developing countries (where we classify countries as high income following the classification in the WDI dataset). For each group, we first calculate the measure of public sector efficiency (PSE) separately, repeating the steps described in sub-section 2.1 above (since the efficiency measure is re-constructed for more homogeneous groups of countries, this can provide an additional robustness test).

Tables 5 and 6 around here

Using these new PSE measures, Tables 5 and 6 rerun the basic regressions of Table 1 for high income and developing countries respectively (again, we present results for the main variables only to save on space). As can be seen, the results remain practically unchanged for the subgroup of high-income countries in Table 5. For the subgroup of developing countries in Table 6, the main story, regarding the importance of the size-efficiency mix, is again supported when we use govshare as a measure of fiscal size (see column (3) in Table 6), which is as in the world sample above. It is interesting to note that, for developing countries, public expenditure is not significantly related to economic growth in the first two columns, but significance is restored in column (3) that explicitly allows for the size-efficiency mix. All this suggests that in both subgroups, our story - that the sizeefficiency mix matters - is confirmed by the data.

We finally report that these results are robust to the inclusion of $\operatorname{tax}$ as an explanatory variable (see subsection 3.4 above). On the other hand, including grolag reduces the sample size in both subgroups too much to give any reliable results.

3.6 Can the size-efficiency mix help with endogeneity?

When looking for a causal effect from fiscal policy in a growth regression, a usual concern is that there might be a reverse causality when e.g. governments respond to negative shocks by increasing 
their expenditure (see e.g. Tanzi and Zee, 1997, and Agell et al., 2006). Although this problem is to some extent mitigated here since we work with 5-year averages, such reverse causality cannot be excluded. In addition, our fiscal size variables, and especially the measure of government efficiency, may be correlated with the error term due to omitted variables or measurement error.

The natural approach to dealing with such an endogeneity is to use instruments for the endogenous variables in IV methods. A fundamental concern with IV regression methods, however, is whether the instruments are valid and relevant. As far as we know, the relevant literature has not yet provided a credible identification of fiscal policy so that the instruments used are both exogenous and strongly correlated with the endogenous variables (see e.g. Agell et al., 2006). We now investigate whether accounting for the size-efficiency mix can help in this direction. We will build upon the basic specification of subsection 3.3.

We need instruments for size and size*eff in 2SLS regressions. As such instruments, we use variables usually considered as potential determinants of fiscal policy (see e.g. Person and Tabellini, 2003, chapter 3). In particular, we use the age dependency ratio (agedep) and two measures of country size (population and surface, denoted respectively as pop and surface). All these three variables are obtained from WDI and, except for surface, are averaged over the 5-year periods. In Table 2, we present results for the core variables when we re-estimate the basic regressions of Table 1 by using these instruments in 2SLS methods (the results for the control variables do not change significantly, so we do not present them to save on space).

\section{Table 7 around here}

We start again with the govshare variable. When we do not account for efficiency (column 1 in Table 7), the Sargan over-identifying restrictions test rejects the null that the instruments are uncorrelated with the error term. However, when efficiency is included as an endogenous variable, either on its own (column 2) or multiplicatively with govshare (column 3), the null clearly cannot be rejected (the p-value is very low in both cases). Therefore, in this sample, the instruments affect growth only indirectly through the size-efficiency mix. Note also that the Anderson (1984) canonical correlations, and the Cragg and Donald (1993) tests of whether the equation is underidentified, reject the null thus lending some support to the relevance of the instruments. ${ }^{18}$ More importantly, the first-stage F-statistic is very high for the govshare*eff variable, which indicates that the instruments are strongly correlated with this variable. Although the first-stage F-statistic for govshare is not as high, it is clear that the diagnostics favor the key regression in column 3 that controls for the size-efficiency mix. In this regression (in column 3), the critical eff ${ }^{*}=1.238$

\footnotetext{
${ }^{18}$ These tests have been implemented using the routines written by Baum et al. (2006).
} 
implies that in 46 countries/periods there is a positive effect on growth from govshare. The fact that the critical efficiency level is lower in the 2SLS regressions indicates that the estimate of fiscal size is biased downwards when endogeneity is not accounted for, so that the "true" effect of fiscal size may in fact be less negative (or more positive) than implied in Table 1 for many countries.

As in Table 1 above, the results are not so promising when we use the govexp variable as a measure of government size. Although the Sargan test does not reject the validity of the instruments, the Anderson (1984) canonical correlations and the Cragg and Donald (1993) tests cannot reject the null that the equation in column 6 of Table 7 is under-identified.

Therefore, although further research is clearly required concerning the issue of causality in the fiscal policy-growth relation in cross-country growth regressions, our results suggest that taking account of the size-efficiency mix can help in identifying the growth effects of fiscal policy.

\subsection{An alternative measure of government efficiency}

To further examine the robustness of our results, we also use the $T E$ measure of efficiency instead of PSE. Again, we will build upon the basic specification of subsection 3.3.

As explained in section 2, we have been able to obtain the TE measure for the 1995-2000 period only. In Table 8, we present results focusing on this period. Actually, in this table, we report results for both the PSE and TE indices of government efficiency, and both the govshare and govexp measures of fiscal size. This has the additional advantage of checking whether there has been a structural break in the size-efficiency-growth relationship of equation (3). The regressions in Table 8 are the same as those in Table 1, except that now we do not include time dummies.

\section{Table 8 around here}

We start again with govshare (columns 1-3). The average effect of govshare is negative (column 1), while the size efficiency mix (when we use the PSE measure for efficiency) is important (column 2). Thus, the non-monotonic relationship holds for both the whole period and the 1995-2000 sub-period. The critical level of efficiency is now eff ${ }^{*}=1.216$, which implies that for 24 out of 51 countries in this period the size-growth relationship is positive. Note also that the regression with the size-efficiency mix is much better that the regression without it, as can be seen by both the increase in $R^{2}$ and the fact that the coefficients of lgdp, openness and East Asia become significant. Regarding lgdp, in particular, this implies that the size-efficiency mix is an important long-run determinant of economic growth that has to be conditioned upon so that convergence can be captured in the data (see e.g. Barro and Sala-i-Martin, 2004, chapter 12, for conditional convergence). 
Then, we estimate equation (3) for the 1995-2000 sample by using TE as the efficiency measure. Results are in column (3). The coefficients are again significant with the right signs. The critical efficiency is now eff ${ }^{*}=0.889$, which implies that only in 8 out of 51 countries in this period the size-growth relationship is positive (see the last column in Table A.2 for the estimated growth effect in each country in this case). These are Finland, Korea, Sweden and Switzerland, as well as (but only marginally) Canada, Germany, Iceland and Uruguay. Note, however, that the regression with the PSE measure in the size-efficiency mix explains about $10 \%$ more of the variation in the growth rate than the regression with the TE measure.

In columns 4-6 of Table 8, we repeat the same regressions by using govexp as a measure of government size. As before, govexp is negative and significant, while the size ${ }^{*} e f f$ variables have a positive sign but are not significant.

As we did in Table 7, we have also run 2SLS regressions for the equations in Table 8 by using the same set of instruments for the size-efficiency mix. The estimated coefficients are again supportive of the importance of the size-efficiency nexus, at least for the govshare measure, but the first stage regression diagnostics reveal that the instruments are not strongly correlated with the endogenous variables. Since the small sample size does not help us to draw any safe conclusions, we find the results of Table 7 to be more reliable. In any case, as discussed above, the identification of fiscal policy remains a challenge in this literature. Finally, we report that with the TE measure of efficiency, we cannot divide countries into rich and developing, as we did in subsection 3.5 (the sub-samples are now too small). Concerning the addition of tax in the regressions (as we did in subsection 3.4 above), we report that once more the main results are not affected.

Therefore, the main result from this subsection is that the relationship between the sizeefficiency mix and economic growth is robust to the time period and the measure of government efficiency used.

\section{Concluding remarks}

We revisited the relationship between fiscal size and economic growth and provided evidence that this relationship depends on the size-efficiency mix of the public sector. The policy implication is that what matters to growth is not the size per se, but the size-efficiency mix. Of course, improving the efficiency of the public sector is not an easy task. It requires, among other things, the reallocation of government resources, as well as the effective and efficient use of those resources towards identified and transparent strategic priorities.

The measurement of government efficiency is still an open issue. The measures developed here, although plausible, cannot be treated as definitive. Future research may provide alternative 
measures to test the robustness of our results. Further research is also needed to investigate the causal effects of fiscal policy on growth in cross-country regressions. We nevertheless believe that we have contributed to these important policy issues. 
TABLE 1: Growth regressions using PSE: 62 countries, 1980-2000

\begin{tabular}{|c|c|c|c|c|c|c|}
\hline $\begin{array}{l}\text { Dep. Variable: } \\
\text { growth rate }\end{array}$ & (1) & (2) & (3) & (4) & (5) & (6) \\
\hline govshare & $\begin{array}{c}-0.052 \\
{[0.023]^{* *}} \\
(0.027)^{*}\end{array}$ & $\begin{array}{c}-0.054 \\
{[0.022]^{* *}} \\
(0.026)^{* *}\end{array}$ & $\begin{array}{c}-0.106 \\
{[0.031]^{* *}} \\
(0.037)^{* *}\end{array}$ & - & - & - \\
\hline govshare*pse & - & - & $\begin{array}{c}0.078 \\
{[0.030]^{* *}} \\
(0.039)^{* *}\end{array}$ & - & - & - \\
\hline govexp & - & - & - & $\begin{array}{c}-0.049 \\
{[0.023]^{* *}} \\
(0.025)^{*}\end{array}$ & $\begin{array}{c}-0.037 \\
{[0.028]} \\
(0.028)\end{array}$ & $\begin{array}{c}-0.053 \\
{[0.025]^{* *}} \\
(0.028)^{*}\end{array}$ \\
\hline govexp*pse & - & - & - & - & - & $\begin{array}{c}0.009 \\
{[0.028]} \\
(0.027)\end{array}$ \\
\hline Pse & - & $\begin{array}{c}0.919 \\
{[0.477]^{*}} \\
(0.567)\end{array}$ & - & - & $\begin{array}{c}0.471 \\
{[0.576]} \\
(0.596)\end{array}$ & - \\
\hline$L g d p$ & $\begin{array}{c}-2.108 \\
{[0.503]^{* *}} \\
(0.720)^{* *}\end{array}$ & $\begin{array}{c}-2.392 \\
{[0.519]^{* *}} \\
(0.671)^{* *}\end{array}$ & $\begin{array}{c}-2.325 \\
{[0.501]^{* *}} \\
(0.636)^{* *}\end{array}$ & $\begin{array}{c}-1.736 \\
{[0.479]^{* *}} \\
(0.686)^{* *}\end{array}$ & $\begin{array}{c}-1.879 \\
{[0.576]^{* *}} \\
(0.664)^{* *}\end{array}$ & $\begin{array}{c}-1.804 \\
{[0.521]^{* *}} \\
(0.670)^{* *}\end{array}$ \\
\hline investment & $\begin{array}{c}0.119 \\
{[0.039]^{* *}} \\
(0.045)^{* *}\end{array}$ & $\begin{array}{c}0.107 \\
{[0.039]^{* *}} \\
(0.047)^{* *}\end{array}$ & $\begin{array}{c}0.118 \\
{[0.038]^{* *}} \\
(0.047)^{* *}\end{array}$ & $\begin{array}{c}0.109 \\
{[0.039]^{* *}} \\
(0.049)^{* *}\end{array}$ & $\begin{array}{c}0.106 \\
{[0.040]^{* *}} \\
(0.049)^{* *}\end{array}$ & $\begin{array}{c}0.108 \\
{[0.040]^{* *}} \\
(0.050)^{* *}\end{array}$ \\
\hline enrolment & $\begin{array}{c}0.015 \\
{[0.014]}\end{array}$ & $\begin{array}{c}0.016 \\
{[0.014]}\end{array}$ & $\begin{array}{c}0.019 \\
{[0.014]}\end{array}$ & $\begin{array}{c}0.025 \\
{[0.015]}\end{array}$ & $\begin{array}{c}0.024 \\
{[0.015]}\end{array}$ & $\begin{array}{c}0.025 \\
{[0.015]}\end{array}$ \\
\hline fertility & $\begin{array}{l}(0.020) \\
-1.677\end{array}$ & $\begin{array}{l}(0.019) \\
-1.522\end{array}$ & $\begin{array}{l}(0.017) \\
-1.275\end{array}$ & $\begin{array}{l}(0.021) \\
-2.136\end{array}$ & $\begin{array}{l}(0.021) \\
-2.017\end{array}$ & $\begin{array}{l}(0.021) \\
-2.078\end{array}$ \\
\hline & $\begin{array}{c}{[0.813]^{* *}} \\
(1.012)\end{array}$ & $\begin{array}{c}{[0.810]^{*}} \\
(1.003)\end{array}$ & $\begin{array}{l}{[0.814]} \\
(0.985)\end{array}$ & $\begin{array}{l}{[0.810]^{* *}} \\
(1.041)^{* *}\end{array}$ & $\begin{array}{c}{[0.824]^{* *}} \\
(1.064)^{*}\end{array}$ & $\begin{array}{c}{[0.830]^{* *}} \\
(1.067)^{*}\end{array}$ \\
\hline openness & $\begin{array}{c}0.011 \\
{[0.004]^{* *}} \\
(0.005)^{* *}\end{array}$ & $\begin{array}{c}0.013 \\
{[0.004]^{* *}} \\
(0.005)^{* *}\end{array}$ & $\begin{array}{c}0.012 \\
{[0.004]^{* *}} \\
(0.005)^{* *}\end{array}$ & $\begin{array}{c}0.011 \\
{[0.004]^{* *}} \\
(0.005)^{* *}\end{array}$ & $\begin{array}{c}0.011 \\
{[0.004]^{* *}} \\
(0.005)^{* *}\end{array}$ & $\begin{array}{c}0.011 \\
{[0.004]^{* *}} \\
(0.005)^{* *}\end{array}$ \\
\hline Sub-Saharan Africa & $\begin{array}{l}-0.227 \\
{[0.996]} \\
(0.706)\end{array}$ & $\begin{array}{c}-0.204 \\
{[0.987]} \\
(0.690)\end{array}$ & $\begin{array}{c}-0.051 \\
{[0.980]} \\
(0.683)\end{array}$ & $\begin{array}{l}-0.372 \\
{[0.992]} \\
(0.708)\end{array}$ & $\begin{array}{c}-0.414 \\
{[0.995]} \\
(0.720)\end{array}$ & $\begin{array}{c}-0.365 \\
{[0.995]} \\
(0.704)\end{array}$ \\
\hline East Asia & $\begin{array}{c}-0.838 \\
{[0.720]} \\
(0.916)\end{array}$ & $\begin{array}{c}-1.794 \\
{[0.869]^{* *}} \\
(1.101)\end{array}$ & $\begin{array}{c}-1.629 \\
{[0.773]^{* *}} \\
(0.883)^{*}\end{array}$ & $\begin{array}{c}-1.156 \\
{[0.784]} \\
(0.944)\end{array}$ & $\begin{array}{c}-1.449 \\
{[0.863]} \\
(1.085)\end{array}$ & $\begin{array}{c}-1.207 \\
{[0.801]} \\
(0.978)\end{array}$ \\
\hline Latin America & $\begin{array}{c}-0.873 \\
{[0.523]^{*}} \\
(0.751)\end{array}$ & $\begin{array}{c}-0.994 \\
{[0.522]^{*}} \\
(0.739)\end{array}$ & $\begin{array}{c}-0.956 \\
{[0.515]^{*}} \\
(0.678)\end{array}$ & $\begin{array}{c}-0.801 \\
{[0.519]} \\
(0.737)\end{array}$ & $\begin{array}{c}-0.797 \\
{[0.520]} \\
(0.738)\end{array}$ & $\begin{array}{c}-0.729 \\
{[0.522]} \\
(0.729)\end{array}$ \\
\hline Transition & -3.601 & -3.478 & -3.329 & -3.280 & -3.289 & -3.240 \\
\hline Economies & $\begin{array}{l}{[0.742]^{* *}} \\
(0.974)^{* *}\end{array}$ & $\begin{array}{l}{[0.738]^{* *}} \\
(1.011)^{* *}\end{array}$ & $\begin{array}{l}{[0.736]^{* *}} \\
(0.984)^{* *}\end{array}$ & $\begin{array}{c}{\left[(0.756]^{* *}\right.} \\
(1.191)^{* *}\end{array}$ & $\begin{array}{l}{\left[(0.757]^{* *}\right.} \\
(1.170)^{* *}\end{array}$ & $\begin{array}{l}{\left[(0.768]^{* *}\right.} \\
(1.211)^{* *}\end{array}$ \\
\hline constant & $\begin{array}{c}19.327 \\
{[4.878]^{* *}} \\
(6.248)^{* *} \\
0.378\end{array}$ & $\begin{array}{c}20.898 \\
{[4.902]^{* *}} \\
(5.908)^{* *} \\
0.394\end{array}$ & $\begin{array}{c}20.269 \\
{[6.609]^{* *}} \\
(5.685)^{* *} \\
0.405\end{array}$ & $\begin{array}{c}16.342 \\
{[4.592]^{* *}} \\
(5.898)^{* *} \\
0.374\end{array}$ & $\begin{array}{c}16.826 \\
{[4.635]^{* *}} \\
(5.763)^{* *} \\
0.377\end{array}$ & $\begin{array}{c}16.801 \\
{[4.807]^{* *}} \\
(5.840)^{* *} \\
0.375\end{array}$ \\
\hline
\end{tabular}

Notes: 1. The estimation method is Least Squares. The sample consists of 62 countries, in 5-year periods over 1980-2000. There is a total of 159 observations. All regressions include time dummies. 2. Standard errors obtained under the assumption of spherical errors are shown in brackets below the estimated coefficients. Standard errors that are robust to arbitrary heteroskedasticity and arbitrary intra-country serial correlation are shown in parentheses. 3 . An asterisk denotes significance at the 10\% level and two asterisks at the $5 \%$ level. 
TABLE 2: Growth regressions using PSE (controlling for tax): 62 countries, 1980-2000

\begin{tabular}{|c|c|c|c|c|c|c|}
\hline Dep. Variable: & (1) & $(2)$ & (3) & (4) & (5) & (6) \\
\hline govshare & $\begin{array}{c}-0.057 \\
{[0.023]^{* *}} \\
(0.026)^{*}\end{array}$ & $\begin{array}{c}-0.056 \\
{[0.023]^{* *}} \\
(0.026)^{* *}\end{array}$ & $\begin{array}{c}-0.103 \\
{[0.032]^{* *}} \\
(0.041)^{* *}\end{array}$ & - & - & - \\
\hline govshare*pse & - & - & $\begin{array}{c}0.072 \\
{[0.035]^{* *}} \\
(0.048)\end{array}$ & - & - & - \\
\hline govexp & - & - & - & $\begin{array}{c}-0.067 \\
{[0.037]^{*}} \\
(0.038)^{*}\end{array}$ & $\begin{array}{c}-0.060 \\
{[0.037]} \\
(0.037)\end{array}$ & $\begin{array}{c}-0.078 \\
{[0.042]^{*}} \\
(0.049)\end{array}$ \\
\hline govexp*pse & - & - & - & - & - & $\begin{array}{c}0.016 \\
{[0.029]} \\
(0.032)\end{array}$ \\
\hline pse & - & $\begin{array}{c}0.748 \\
{[0.594]} \\
(0.699)\end{array}$ & - & - & $\begin{array}{c}0.656 \\
{[0.609]} \\
(0.693)\end{array}$ & - \\
\hline $\operatorname{tax}$ & $\begin{array}{c}-0.039 \\
{[0.026]} \\
(0.030)\end{array}$ & $\begin{array}{c}-0.015 \\
{[0.032]} \\
(0.038)\end{array}$ & $\begin{array}{c}-0.011 \\
{[0.029]} \\
(0.036)\end{array}$ & $\begin{array}{c}0.024 \\
{[0.040]} \\
(0.050)\end{array}$ & $\begin{array}{c}0.039 \\
{[0.042]} \\
(0.055)\end{array}$ & $\begin{array}{c}0.032 \\
{[0.042]} \\
(0.056)\end{array}$ \\
\hline$R^{2}$ & 0.388 & 0.395 & 0.405 & 0.376 & 0.381 & 0.377 \\
\hline
\end{tabular}

Notes: 1. The estimation method is Least Squares. The sample consists of 62 countries, in 5-year periods over 1980-2000. There is a total of 159 observations. All regressions include time dummies, regional dummies and the control variables of the regressions in Table 1. 2. Standard errors obtained under the assumption of spherical errors are shown in brackets below the estimated coefficients. Standard errors that are robust to arbitrary heteroskedasticity and arbitrary intra-country serial correlation are shown in parentheses. 3. An asterisk denotes significance at the 10\% level and two asterisks at the $5 \%$ level.

TABLE 3: Growth regressions using PSE (controlling for grolag): 46 countries, 1985-2000

\begin{tabular}{|c|c|c|c|c|c|c|}
\hline Dep. Variable: & (1) & (2) & (3) & (4) & (5) & (6) \\
\hline govshare & $\begin{array}{c}-0.071 \\
{[0.033]^{* *}} \\
(0.038)^{*}\end{array}$ & $\begin{array}{c}-0.082 \\
{[0.033]^{* *}} \\
(0.036)^{* *}\end{array}$ & $\begin{array}{c}-0.165 \\
{[0.053]^{* *}} \\
(0.049)^{* *}\end{array}$ & - & - & - \\
\hline govshare*pse & - & - & $\begin{array}{c}0.103 \\
{[0.0474]^{* *}} \\
(0.057)\end{array}$ & - & - & - \\
\hline govexp & - & - & - & $\begin{array}{c}-0.054 \\
{[0.031]^{*}} \\
(0.024)^{* *}\end{array}$ & $\begin{array}{c}-0.047 \\
{[0.036]} \\
(0.031)\end{array}$ & $\begin{array}{c}-0.055 \\
{[0.035]} \\
(0.030)^{*}\end{array}$ \\
\hline govexp*pse & - & - & - & - & - & $\begin{array}{c}0.001 \\
{[0.034]} \\
(0.039)\end{array}$ \\
\hline pse & - & $\begin{array}{c}1.120 \\
{[0.679]} \\
(0.674)\end{array}$ & - & - & $\begin{array}{c}0.282 \\
{[0.796]} \\
(0.837)\end{array}$ & - \\
\hline grolag & $\begin{array}{c}0.198 \\
{[0.104]^{*}} \\
(0.139)\end{array}$ & $\begin{array}{c}0.182 \\
{[0.103]^{*}} \\
(0.135)\end{array}$ & $\begin{array}{c}0.131 \\
{[0.106]} \\
(0.124)\end{array}$ & $\begin{array}{c}0.225 \\
{[0.104]^{* *}} \\
(0132)^{*}\end{array}$ & $\begin{array}{c}0.223 \\
{[0.105]^{* *}} \\
(0.131)^{*}\end{array}$ & $\begin{array}{c}0.225 \\
{[0.105]^{* *}} \\
(0.137)\end{array}$ \\
\hline$R^{2}$ & 0.458 & 0.475 & 0.487 & 0.448 & 0.448 & 0.448 \\
\hline
\end{tabular}

Notes: 1. The estimation method is Least Squares. The sample consists of 46 countries, in 5-year periods over 1985-2000. There is a total of 98 observations. All regressions time dummies, regional dummies and the control variables of the regressions in Table 1. 2. Standard errors obtained under the assumption of spherical errors are shown in brackets below the estimated coefficients. Standard errors that are robust to arbitrary heteroskedasticity and arbitrary intra-country serial correlation are shown in parentheses. 3. An asterisk denotes significance at the $10 \%$ level and two asterisks at the $5 \%$ level. 
TABLE 4: Growth regressions using PSE (controlling for tax and grolag): 46 countries, 19852000

\begin{tabular}{|c|c|c|c|c|c|c|}
\hline $\begin{array}{c}\text { Dep. Variable: } \\
\text { growth rate }\end{array}$ & $\overline{(1)}$ & $\overline{(2)}$ & (3) & $\overline{(4)}$ & (5) & (6) \\
\hline govshare & $\begin{array}{c}-0.074 \\
{[0.034]^{* *}} \\
(0.036)^{* *}\end{array}$ & $\begin{array}{c}-0.079 \\
{[0.033]^{* *}} \\
(0.036)^{* *}\end{array}$ & $\begin{array}{c}-0.190 \\
{[0.058]^{* *}} \\
(0.061)^{* *}\end{array}$ & - & - & - \\
\hline govshare*pse & - & - & $\begin{array}{c}0.140 \\
{[0.057]^{* *}} \\
(0.077)^{*}\end{array}$ & - & - & - \\
\hline govexp & - & - & - & $\begin{array}{c}-0.151 \\
{[0.049]^{* *}} \\
(0.056)^{* *}\end{array}$ & $\begin{array}{c}-0.150 \\
{[0.049]^{* *}} \\
(0.056)^{* *}\end{array}$ & $\begin{array}{c}-0.207 \\
{[0.063]^{* *}} \\
(0.072)^{* *}\end{array}$ \\
\hline govexp*pse & - & - & - & - & - & $\begin{array}{c}0.054 \\
{[0.034]} \\
(0.049\end{array}$ \\
\hline pse & - & $\begin{array}{c}1.585 \\
{[0.868]} \\
(1.026)\end{array}$ & - & - & $\begin{array}{c}1.373 \\
{[0.847]} \\
(0.940)\end{array}$ & - \\
\hline $\operatorname{tax}$ & $\begin{array}{l}-0.011 \\
{[0.033]}\end{array}$ & $\begin{array}{l}-0.035 \\
{[0.041]}\end{array}$ & $\begin{array}{c}0.043 \\
{[0.039]}\end{array}$ & $\begin{array}{c}0.127 \\
{[0.051]^{* *}}\end{array}$ & $\begin{array}{c}0.168 \\
{[0.057]^{* *}}\end{array}$ & $\begin{array}{c}0.168 \\
{[0.059]^{* *}}\end{array}$ \\
\hline arolag & $\begin{array}{l}(0.030) \\
0.198\end{array}$ & $\begin{array}{c}(0.046) \\
0.176\end{array}$ & $\begin{array}{c}(0.043) \\
0.107\end{array}$ & $\begin{array}{c}(0.063)^{* *} \\
0.208\end{array}$ & $\begin{array}{c}(0.069)^{* *} \\
0.191\end{array}$ & $\begin{array}{c}(0.077)^{* *} \\
0.213\end{array}$ \\
\hline & $\begin{array}{c}{[0.104]^{*}} \\
(0.139)\end{array}$ & $\begin{array}{c}{[0.104]^{*}} \\
(0.138)\end{array}$ & $\begin{array}{r}{[0.108]} \\
(0.125)\end{array}$ & $\begin{array}{c}{[0.101]^{* *}} \\
(0.128)\end{array}$ & $\begin{array}{c}{[0.101]^{*}} \\
(0.129)\end{array}$ & $\begin{array}{c}{[0.101]^{* *}} \\
(0.135)\end{array}$ \\
\hline$R^{2}$ & 0.458 & 0.479 & 0.495 & 0.485 & 0.501 & 0.497 \\
\hline
\end{tabular}

Notes: 1. The estimation method is Least Squares. The sample consists of 46 countries, in 5-year periods over 1985-2000. There is a total of 98 observations. All regressions include time dummies, regional dummies and the control variables of the regressions in Table 1. 2. Standard errors obtained under the assumption of spherical errors are shown in brackets below the estimated coefficients. Standard errors that are robust to arbitrary heteroskedasticity and arbitrary intra-country serial correlation are shown in parentheses. 3. An asterisk denotes significance at the $10 \%$ level and two asterisks at the 5\% level. 
TABLE 5: Growth regressions using PSE (high income countries): 26 countries, 1980-2000

\begin{tabular}{|c|c|c|c|c|c|c|}
\hline $\begin{array}{c}\text { Dep. Variable: } \\
\text { arowth rate }\end{array}$ & (1) & (2) & (3) & (4) & (5) & (6) \\
\hline govshare & $\begin{array}{c}-0.065 \\
{[0.028]^{* *}} \\
(0.038)^{*}\end{array}$ & $\begin{array}{c}-0.057 \\
{[0.027]^{* *}} \\
(0.032)^{*}\end{array}$ & $\begin{array}{c}-0.173 \\
{[0.042]^{* *}} \\
(0.050)^{* *}\end{array}$ & - & - & - \\
\hline govshare*pse & . & - & $\begin{array}{c}0.124 \\
{[0.038]^{* *}} \\
(0.040)^{* *}\end{array}$ & - & - & - \\
\hline govexp & - & - & - & $\begin{array}{c}-0.079 \\
{[0.016]^{* *}} \\
(0.020)^{* *}\end{array}$ & $\begin{array}{c}-0.072 \\
{[0.022]^{* *}} \\
(0.024)^{* *}\end{array}$ & $\begin{array}{c}-0.080 \\
{[0.016]^{* *}} \\
(0.020)^{* *}\end{array}$ \\
\hline govexp*pse & - & - & - & - & - & $\begin{array}{c}0.004 \\
{[0.023]} \\
(0.019)\end{array}$ \\
\hline pse & - & $\begin{array}{c}1.161 \\
{[0.358]^{* *}} \\
(0.345)^{* *}\end{array}$ & - & - & $\begin{array}{c}0.211 \\
{[0.465]} \\
(0.314)\end{array}$ & - \\
\hline$R^{2}$ & 0.599 & 0.649 & 0.649 & 0.673 & 0.674 & 0.674 \\
\hline
\end{tabular}

Notes: 1. The estimation method is Least Squares. The sample consists of 26 countries, in 5-year periods over 1980-2000. There is a total of 85 observations. All regressions include time dummies and the control variables of the regressions in Table 1. 2. Standard errors obtained under the assumption of spherical errors are shown in brackets below the estimated coefficients. Standard errors that are robust to arbitrary heteroskedasticity and arbitrary intracountry serial correlation are shown in parentheses. 3. An asterisk denotes significance at the $10 \%$ level and two asterisks at the $5 \%$ level.

TABLE 6: Growth regressions using PSE (developing countries): 36 countries, 1980-2000

\begin{tabular}{|c|c|c|c|c|c|c|}
\hline Dep. Variable: & (1) & (2) & (3) & (4) & (5) & (6) \\
\hline govshare & $\begin{array}{c}-0.022 \\
{[0.035]} \\
(0.037)\end{array}$ & $\begin{array}{c}-0.010 \\
{[0.036]} \\
(0.038)\end{array}$ & $\begin{array}{c}-0.069 \\
{[0.041]^{*}} \\
(0.049)\end{array}$ & - & - & - \\
\hline govshare*pse & - & - & $\begin{array}{c}0.078 \\
{[0.037]^{* *}} \\
(0.044)^{*}\end{array}$ & - & - & - \\
\hline govexp & - & - & - & $\begin{array}{c}-0.026 \\
{[0.036]} \\
(0.040)\end{array}$ & $\begin{array}{c}0.012 \\
{[0.047]} \\
(0.045)\end{array}$ & $\begin{array}{c}-0.056 \\
{[0.039]} \\
(0.046)\end{array}$ \\
\hline govexp*pse & - & - & - & - & - & $\begin{array}{c}0.090 \\
{[0.050]^{*}} \\
(0.057)\end{array}$ \\
\hline pse & - & $\begin{array}{l}1.127 \\
{[0.848]} \\
(1.131)\end{array}$ & - & - & $\begin{array}{c}1.362 \\
{[1.072]} \\
(1.327)\end{array}$ & - \\
\hline$R^{2}$ & 0.191 & 0.213 & 0.243 & 0.192 & 0.212 & 0.238 \\
\hline
\end{tabular}

Notes: 1. The estimation method is Least Squares. The sample consists of 36 countries, in 5-year periods over 1980-2000. There is a total of 74 observations. All regressions include time dummies and the control variables of the regressions in Table 1. 2. Standard errors obtained under the assumption of spherical errors are shown in brackets below the estimated coefficients. Standard errors that are robust to arbitrary heteroskedasticity and arbitrary intracountry serial correlation are shown in parentheses. 3. An asterisk denotes significance at the $10 \%$ level and two asterisks at the $5 \%$ level. 
TABLE 7: Growth regressions using PSE: 2SLS for 62 countries, 1980-2000

\begin{tabular}{|c|c|c|c|c|c|c|}
\hline $\begin{array}{c}\text { Dep. variable: } \\
\text { growth rate }\end{array}$ & (1) & (2) & (3) & (4) & (5) & (6) \\
\hline govshare & $\begin{array}{c}-0.126 \\
{[0.067]^{*}} \\
(0.088)\end{array}$ & $\begin{array}{c}-0.160 \\
{[0.082]^{*}} \\
(0.096)^{*}\end{array}$ & $\begin{array}{c}-0.208 \\
{[0.071]^{* *}} \\
(0.081)^{* *}\end{array}$ & - & - & - \\
\hline govshare*pse & - & - & $\begin{array}{c}0.168 \\
{[0.053]^{* *}} \\
(0.054)^{* *}\end{array}$ & - & - & - \\
\hline govexp & - & - & - & $\begin{array}{c}-0.096 \\
{[0.050]^{*}} \\
(0.059)\end{array}$ & $\begin{array}{c}0.028 \\
{[0.094]} \\
(0.123)\end{array}$ & $\begin{array}{c}-0.225 \\
{[0.106]^{* *}} \\
(0.107)^{* *}\end{array}$ \\
\hline govexp*pse & - & - & - & - & - & $\begin{array}{c}0.314 \\
{[0.198]} \\
(0.205)\end{array}$ \\
\hline pse & - & $\begin{array}{c}4.826 \\
{[1.902]^{* *}} \\
(1.775)^{* *}\end{array}$ & - & - & $\begin{array}{c}4.880 \\
{[2.848]} \\
(2.718)\end{array}$ & - \\
\hline $\begin{array}{c}\text { Sargan over- } \\
\text { identification test }\end{array}$ & $\begin{array}{c}\chi_{(2)}^{2}=9.513 \\
(0.008)\end{array}$ & $\begin{array}{c}\chi_{(1)}^{2}=0.110 \\
(0.739)\end{array}$ & $\begin{array}{l}\chi_{(1)}^{2}=0.029 \\
(0.865)\end{array}$ & $\begin{array}{l}\chi_{(2)}^{2}=9.894 \\
(0.007)\end{array}$ & $\begin{array}{c}\chi_{(1)}^{2}=4.144 \\
(0.041)\end{array}$ & $\begin{array}{c}\chi_{(1)}^{2}=2.902 \\
(0.088)\end{array}$ \\
\hline $\begin{array}{l}\text { Cragg-Donald } \\
\text { Under- } \\
\text { identification }\end{array}$ & $\begin{array}{c}\chi_{(3)}^{2}=20.78 \\
(0.000)\end{array}$ & $\begin{array}{c}\chi_{(2)}^{2}=15.12 \\
(0.000)\end{array}$ & $\begin{array}{l}\chi_{(2)}^{2}=19.88 \\
(0.000)\end{array}$ & $\begin{array}{c}\chi_{(3)}^{2}=42.17 \\
(0.000)\end{array}$ & $\begin{array}{c}\chi_{(2)}^{2}=8.96 \\
(0.011)\end{array}$ & $\begin{array}{c}\chi_{(2)}^{2}=5.56 \\
(0.061)\end{array}$ \\
\hline $\begin{array}{l}\text { Anderson canonical } \\
\text { correlations }\end{array}$ & $\begin{array}{c}\chi_{(3)}^{2}=19.53 \\
(0.000)\end{array}$ & $\begin{array}{c}\chi_{(2)}^{2}=14.44 \\
(0.000)\end{array}$ & $\begin{array}{c}\chi_{(2)}^{2}=18.73 \\
(0.000)\end{array}$ & $\begin{array}{c}\chi_{(3)}^{2}=37.40 \\
(0.000)\end{array}$ & $\begin{array}{c}\chi_{(2)}^{2}=8.72 \\
(0.012)\end{array}$ & $\begin{array}{c}\chi_{(2)}^{2}=5.469 \\
(0.064)\end{array}$ \\
\hline First-stage & $F(3,143)=$ & $F(3,143)=$ & $F(3,143)=$ & $F(3,143)=$ & $F(3,143)=$ & $F(3,143)=$ \\
\hline F (gov) & 6.23 & 6.23 & 6.23 & 12.64 & 12.64 & 12.64 \\
\hline $\begin{array}{c}\text { First-stage } \\
\text { F (pse) }\end{array}$ & - & $\begin{array}{c}F(3,143)= \\
4.91\end{array}$ & - & - & $\begin{array}{c}F(3,143)= \\
4.91\end{array}$ & - \\
\hline $\begin{array}{l}\text { First-stage } \\
\text { F (gov*pse) }\end{array}$ & - & - & $\begin{array}{c}F(3,143)= \\
11.95\end{array}$ & - & - & $\begin{array}{c}F(3,143)= \\
3.59\end{array}$ \\
\hline
\end{tabular}

Notes: Notes: 1. The estimation method is 2SLS. The sample consists of 62 countries, in 5-year periods over 19802000. There is a total of 159 observations. All regressions include time dummies, regional dummies and the control variables of the regressions in Table 1. 2. Standard errors obtained under the assumption of spherical errors are shown in brackets below the estimated coefficients. Standard errors that are robust to arbitrary heteroskedasticity and arbitrary intra-country serial correlation are shown in parentheses. 3 . An asterisk denotes significance at the $10 \%$ level and two asterisks at the 5\% level. 4. The instruments used are: agedep, pop, surface. 5. The Sargan test is a test of overidentifying restrictions. Under the null, the test statistic is distributed as chi-squared in the number of over-identifying restrictions (the p-value is reported in parenthesis). 6. The Anderson (1984) canonical correlation is a likelihood-ratio test of whether the equation is identified. The Cragg and Donald (1993) test statistic is also a chi-squared test of whether the equation is identified. Under the null of underidentification, the statistics are distributed as chi-squared with degrees of freedom $=(L-K+1)$ where $L=n u m b e r$ of instruments (included + excluded) and $K$ is the number of regressors (the p-values are reported in parentheses). 7. The $1^{\text {st }}$ stage F-statistic tests the hypothesis that the coefficients on all the excluded instruments are zero in the $1^{\text {st }}$ stage regression of the endogenous regressor on all instruments (the p-value is reported in parenthesis). 
TABLE 8: Growth regressions using PSE and TE: OLS for 51 countries, 1995-2000

\begin{tabular}{|c|c|c|c|c|c|c|}
\hline $\begin{array}{l}\text { Dep. variable: } \\
\text { Growth rate }\end{array}$ & (1) & (2) & (3) & (4) & (5) & (6) \\
\hline govshare & $\begin{array}{c}-0.088 \\
{[0.049]^{*}} \\
(0.048)^{*}\end{array}$ & $\begin{array}{c}-0.202 \\
{[0.055]^{* *}} \\
(0.055)^{* *}\end{array}$ & $\begin{array}{c}-0.225 \\
{[0.088]^{* *}} \\
(0.083)^{* *}\end{array}$ & - & - & - \\
\hline govshare*pse & - & $\begin{array}{c}0.166 \\
{[0.050]^{* *}} \\
(0.046)^{* *}\end{array}$ & - & - & - & - \\
\hline govshare*te & - & - & $\begin{array}{c}0.253 \\
{[0.137]^{*}} \\
(0.130)^{*}\end{array}$ & - & - & - \\
\hline govexp & - & - & - & $\begin{array}{c}-0.138 \\
{[0.055]^{* *}} \\
(0.049)^{* *}\end{array}$ & $\begin{array}{c}-0.148 \\
{[0.047]^{* *}} \\
(0.056)^{* *}\end{array}$ & $\begin{array}{c}-0.187 \\
{[0.089]^{* *}} \\
(0.088)^{* *}\end{array}$ \\
\hline govexp*pse & - & - & - & - & $\begin{array}{c}0.047 \\
{[0.060]} \\
(0.045)\end{array}$ & - \\
\hline govexp*te & - & - & - & - & - & $\begin{array}{c}0.081 \\
{[0.113]} \\
(0.098)\end{array}$ \\
\hline $\lg d p$ & $\begin{array}{c}-1.143 \\
{[1.027]} \\
(1.344)\end{array}$ & $\begin{array}{c}-1.185 \\
{[0.943]^{*}} \\
(1.094)^{*}\end{array}$ & $\begin{array}{c}-1.899 \\
{[1.079]^{*}} \\
(1.275)\end{array}$ & $\begin{array}{c}-0.676 \\
{[0.908]} \\
(0.992)\end{array}$ & $\begin{array}{c}-0.940 \\
{[0.972]} \\
(1.078)\end{array}$ & $\begin{array}{l}-0.994 \\
{[1.015]} \\
(1.091)\end{array}$ \\
\hline investment & $\begin{array}{c}0.040 \\
{[0.076]} \\
(0.093)\end{array}$ & $\begin{array}{c}0.040 \\
{[0.068]} \\
(0.089)\end{array}$ & $\begin{array}{c}0.024 \\
{[0.074]} \\
(0.091)\end{array}$ & $\begin{array}{c}0.035 \\
{[0.073]} \\
(0.095)\end{array}$ & $\begin{array}{c}0.031 \\
{[0.074]} \\
(0.093)\end{array}$ & $\begin{array}{c}0.026 \\
{[0.075]} \\
(0.094)\end{array}$ \\
\hline enrolment & $\begin{array}{c}0.015 \\
{[0.027]} \\
(0.034)\end{array}$ & $\begin{array}{c}0.029 \\
{[0.025]} \\
(0.028)\end{array}$ & $\begin{array}{c}0.014 \\
{[0.026]} \\
(0.033)\end{array}$ & $\begin{array}{c}0.046 \\
{[0.030]} \\
(0.030)\end{array}$ & $\begin{array}{c}0.039 \\
{[0.031]} \\
(0.032)\end{array}$ & $\begin{array}{c}0.043 \\
{[0.304]} \\
(0.031)\end{array}$ \\
\hline fertility & $\begin{array}{c}0.025 \\
{[1.679]} \\
(1.359)\end{array}$ & $\begin{array}{l}0.502 \\
{[1.508]} \\
(1.260)\end{array}$ & $\begin{array}{l}-0.069 \\
{[1.632]} \\
(1.384)\end{array}$ & $\begin{array}{l}-1.388 \\
{[1.528]} \\
(1.105)\end{array}$ & $\begin{array}{c}-1.087 \\
{[1.582]} \\
(1.158)\end{array}$ & $\begin{array}{c}-1.409 \\
{[1.538]} \\
(1.122)\end{array}$ \\
\hline openness & $\begin{array}{c}0.012 \\
{[0.008]} \\
(0.010)\end{array}$ & $\begin{array}{c}0.019 \\
{[0.008]^{* *}} \\
(0.009)^{* *}\end{array}$ & $\begin{array}{c}0.012 \\
{[0.008]} \\
(0.011)\end{array}$ & $\begin{array}{c}0.018 \\
{[0.009]^{* *}} \\
(0.010)^{*}\end{array}$ & $\begin{array}{c}0.017 \\
{[0.009]^{*}} \\
(0.010)^{*}\end{array}$ & $\begin{array}{c}0.018 \\
{[0.009]^{* *}} \\
(0.011)^{*}\end{array}$ \\
\hline $\begin{array}{c}\text { Sub-Saharan } \\
\text { Africa }\end{array}$ & $\begin{array}{c}-0.929 \\
{[1.803]} \\
(0.960)\end{array}$ & $\begin{array}{l}-0.535 \\
{[1.617]} \\
(1.000)\end{array}$ & $\begin{array}{l}-1.262 \\
{[1.761]} \\
(0.974)\end{array}$ & $\begin{array}{c}-0.348 \\
{[1.776]} \\
(0.877)\end{array}$ & $\begin{array}{c}-0.347 \\
{[1.785]} \\
(0.905)\end{array}$ & $\begin{array}{c}-0.247 \\
{[1.793]} \\
(0.906)\end{array}$ \\
\hline East Asia & $\begin{array}{c}-1.903 \\
{[1.709]} \\
(1.814)\end{array}$ & $\begin{array}{c}-3.923 \\
{[1.645]^{* *}} \\
(1.893)^{* *}\end{array}$ & $\begin{array}{l}-2.774 \\
{[1.726]} \\
(1.934)\end{array}$ & $\begin{array}{c}-4.179 \\
{[2.020]^{* *}} \\
(1.768)^{* *}\end{array}$ & $\begin{array}{c}-3.895 \\
{[2.061]^{*}} \\
(1.875)^{* *}\end{array}$ & $\begin{array}{c}-4.122 \\
{[2.034]^{* *}} \\
(1.966)^{* *}\end{array}$ \\
\hline Latin America & $\begin{array}{c}-1.191 \\
{[0.980]} \\
(1.039)\end{array}$ & $\begin{array}{c}-1.470 \\
{[0.881]} \\
(0.903)\end{array}$ & $\begin{array}{l}-1.341 \\
{[0.956]} \\
(1.056)\end{array}$ & $\begin{array}{c}-1.316 \\
{[0.942]} \\
(0.958)\end{array}$ & $\begin{array}{c}-1.181 \\
{[0.962]} \\
(0.922)\end{array}$ & $\begin{array}{l}-1.199 \\
{[0.976]} \\
(0.950)\end{array}$ \\
\hline Transition & -3.617 & -3.854 & -3.738 & -4.104 & -3.871 & -3.768 \\
\hline Economies & $\begin{array}{l}{[1.608]^{* *}} \\
(1.705)^{* *}\end{array}$ & $\begin{array}{l}{[1.440]^{* *}} \\
(1.590)^{* *}\end{array}$ & $\begin{array}{l}{[1.564]^{* *}} \\
(1.697)^{* *}\end{array}$ & $\begin{array}{l}{[1.551]^{* *}} \\
(2.063)^{* *}\end{array}$ & $\begin{array}{c}{[1.586]^{* *}} \\
(2.025)^{*}\end{array}$ & $\begin{array}{c}{[1.629]^{* *}} \\
(2.029)^{*}\end{array}$ \\
\hline Constant & $\begin{array}{c}12.004 \\
{[9.003]} \\
(10.020)\end{array}$ & $\begin{array}{c}16.093 \\
{[8.146]^{*}} \\
(7.823)\end{array}$ & $\begin{array}{l}19.240 \\
{[9.588]} \\
(9.638)\end{array}$ & $\begin{array}{l}8.906 \\
{[7.980]} \\
(7.423)\end{array}$ & $\begin{array}{l}10.497 \\
{[8.257]} \\
(7.951)^{*}\end{array}$ & $\begin{array}{c}12.026 \\
{[8.986]} \\
(8.143)^{*}\end{array}$ \\
\hline$R^{2}$ & 0.291 & 0.446 & 0.347 & 0.335 & 0.346 & 0.344 \\
\hline
\end{tabular}

Notes: 1. The estimation method is OLS. The sample consists of 51 countries, 1985-2000. There are 51 observations. 2.-3. As in Table 1. 


\section{APPENDIX: construction of PSE}

We construct measures of public sector efficiency (PSE) for 64 countries, in four 5-year periods, over 1980-2000, as output-to-input ratios by working as in Afonso et al. (2005). Afonso et al. have focused on OECD countries, where the available data cover both government performance and the associated public expenditure. Although we have tried to follow Afonso et al. in the choice of policy areas and variables used, the construction of such a rich PSE for a broader group of countries runs into data limitations, especially when looking for decomposed public expenditure data. Thus, some deviations from the variables used by Afonso et al. are inevitable. Nevertheless, the variables used here are the same in spirit.

In the policy area of education, the PSP can be measured by the variable Secondary School Enrollment, while the associated PEX is the average of the variable Public Spending in Education as a percentage of GDP (both variables are available from the World Development Indicators, WDI), where we use the end of period values (or the closest to the end available) of Secondary School Enrollment. ${ }^{19}$ The resulting PSE is then a measure of government efficiency in the policy area of education.

In the policy area of administration, the PSP is measured by the end of period values of the variables Corruption in Government and Bureaucratic Quality (both obtained from the IRIS-3 dataset) ${ }^{20}$ with higher scores denoting better outcomes, while the PSE is obtained as in Afonso et al. (2005) by dividing this variable by the average public spending on goods and services (available from WDI).

In the policy area of infrastructure, the PSP is measured by the average of Diesel Locomotives in Use as a percentage of total locomotives, and the average of the inverse of Electric Power Transmission and Distribution Losses (both variables are available from WDI). These measures have also been used by Tanzi and Davoodi (1998) as indicators of the quality of infrastructure (see also Angelopoulos and Philippopoulos, 2007). A problem here is that the relevant PEX for infrastructure quality, which has been used by Afonso et al. for the OECD countries, is not available for the larger group of countries we work with. We

\footnotetext{
${ }^{19}$ Afonso et al. (2005) use the same PEX, but they also include a measure of the quality of education when they construct the PSP.

${ }^{20}$ Afonso et al. (2005) have used very similar variables (measures of corruption, red tape, quality of judiciary and shadow economy). We prefer the IRIS-3 indexes because they are available for the counties and time periods we work with.
} 
therefore choose to use Total Government Expenditure (as a percentage of GDP) for PEX (this is also available from WDI), again averaged over the 5-year period.

Finally, in the policy area of stabilization, the PSP is measured by the average of the inverse of the variables Inflation Rate and Unemployment Rate (obtained from WDI), while the relevant PSE is calculated by dividing this PSP by Total Government Expenditure (as a percentage of GDP), averaged over the 5-year period. Afonso et al. also use total government spending as a measure of public sector expenditures that are associated with stabilization and economic performance indicators, such as inflation and unemployment. 
Table A.1: Public Sector Efficiency (PSE) in 64 countries, 1980-2000

\begin{tabular}{|c|c|c|c|c|c|c|c|c|c|c|c|}
\hline Country & Period & $\begin{array}{l}P S P- \\
\text { Admin }\end{array}$ & $\begin{array}{l}\text { PSP- } \\
\text { Educ }\end{array}$ & $\begin{array}{l}\text { PSP- } \\
\text { Infrast }\end{array}$ & $\begin{array}{l}\text { PSP- } \\
\text { Stabil }\end{array}$ & $\begin{array}{l}\text { PSE- } \\
\text { Admin }\end{array}$ & $\begin{array}{l}\text { PSE- } \\
\text { Educ }\end{array}$ & $\begin{array}{l}\text { PSE- } \\
\text { Infrast }\end{array}$ & $\begin{array}{l}\text { PSE- } \\
\text { Stabil }\end{array}$ & $\begin{array}{l}P S E- \\
\text { average }\end{array}$ & $\begin{array}{l}\text { Growth } \\
\text { effect }\end{array}$ \\
\hline Algeria & $\begin{array}{l}1990- \\
1995\end{array}$ & 0.557 & 0.793 & 0.797 & 0.258 & 0.466 & 0.648 & 0.749 & 0.242 & 0.526 & -0.065 \\
\hline Algeria & $\begin{array}{l}1995- \\
2000\end{array}$ & 0.586 & 0.803 & 0.452 & 0.233 & 0.522 & 0.73 & 0.459 & 0.237 & 0.487 & -0.068 \\
\hline Argentina & $\begin{array}{l}1995- \\
2000 \\
\end{array}$ & 0.592 & 1.013 & 0.528 & 2.092 & 1.763 & 1.366 & 1.043 & 4.136 & 2.077 & - \\
\hline Australia & $\begin{array}{l}1980- \\
1985\end{array}$ & 1.266 & 1.108 & 0.972 & 0.78 & 2.374 & 1.048 & 1.357 & 1.089 & 1.467 & 0.008 \\
\hline Australia & $\begin{array}{l}1985- \\
1990\end{array}$ & 1.309 & 1.169 & 1.015 & 0.552 & 2.053 & 1.079 & 1.296 & 0.705 & 1.283 & -0.006 \\
\hline Australia & $\begin{array}{l}1990- \\
1995\end{array}$ & 1.224 & 1.226 & 0.997 & 1.316 & 1.754 & 1.122 & 1.243 & 1.64 & 1.44 & 0.006 \\
\hline Australia & $\begin{array}{l}1995- \\
2000\end{array}$ & 1.306 & 1.222 & 1.26 & 1.149 & 1.954 & 1.218 & 1.603 & 1.462 & 1.559 & 0.016 \\
\hline Austria & $\begin{array}{l}1985- \\
1990\end{array}$ & 1.309 & 1.354 & 1.214 & 1.409 & 1.257 & 1.074 & 0.981 & 1.139 & 1.113 & -0.019 \\
\hline Austria & $\begin{array}{l}1990- \\
1995\end{array}$ & 1.224 & 1.255 & 1.043 & 1.701 & 1.196 & 1.083 & 0.831 & 1.355 & 1.116 & -0.019 \\
\hline Austria & $\begin{array}{l}1995- \\
2000\end{array}$ & 1.257 & 1.212 & 1.247 & 1.709 & 1.197 & 1.042 & 0.956 & 1.31 & 1.127 & -0.018 \\
\hline Belgium & $\begin{array}{l}1980- \\
1985\end{array}$ & 1.384 & 1.254 & 1.332 & 1.22 & 1.181 & 1.069 & 0.814 & 0.745 & 0.952 & -0.032 \\
\hline Belgium & $\begin{array}{l}1985- \\
1990\end{array}$ & 1.285 & 1.303 & 1.279 & 1.108 & 1.243 & 1.12 & 0.791 & 0.686 & 0.96 & -0.031 \\
\hline Belgium & $\begin{array}{l}1990- \\
1995\end{array}$ & 1.156 & 1.24 & 1.155 & 1.154 & 1.242 & 1.114 & 0.735 & 0.734 & 0.956 & -0.031 \\
\hline Bolivia & $\begin{array}{l}1985- \\
1990 \\
\end{array}$ & 0.359 & 0.437 & 0.691 & 0.23 & 0.404 & 0.935 & 1.584 & 0.527 & 0.863 & -0.039 \\
\hline Brazil & $\begin{array}{l}1990- \\
1995\end{array}$ & 0.778 & 0.275 & 0.42 & 0.553 & 1.599 & 0.78 & 0.41 & 0.539 & 0.832 & -0.041 \\
\hline Bulgaria & $\begin{array}{l}1990- \\
1995\end{array}$ & 0.78 & 1.056 & 0.724 & 0.24 & 0.565 & 0.934 & 0.499 & 0.166 & 0.541 & -0.064 \\
\hline Bulgaria & $\begin{array}{l}1995- \\
2000\end{array}$ & 0.836 & 1.111 & 0.618 & 0.239 & 0.792 & 1.606 & 0.502 & 0.194 & 0.773 & -0.046 \\
\hline Canada & $\begin{array}{l}1980- \\
1985\end{array}$ & 1.384 & 1.247 & 1.107 & 0.728 & 2.715 & 0.921 & 1.559 & 1.026 & 1.555 & 0.015 \\
\hline Canada & $\begin{array}{l}1985- \\
1990\end{array}$ & 1.429 & 1.318 & 1.105 & 0.686 & 2.712 & 0.924 & 1.432 & 0.889 & 1.489 & 0.010 \\
\hline Canada & $\begin{array}{l}1990- \\
1995\end{array}$ & 1.336 & 1.284 & 1.037 & 1.379 & 2.457 & 0.873 & 1.197 & 1.592 & 1.53 & 0.013 \\
\hline Canada & $\begin{array}{l}1995- \\
2000\end{array}$ & 1.428 & 1.288 & 1.187 & 1.266 & 3.654 & 1.13 & 1.631 & 1.741 & 2.039 & 0.053 \\
\hline Chile & $\begin{array}{l}1985- \\
1990\end{array}$ & 0.715 & 0.811 & 0.638 & 0.374 & 0.936 & 1.08 & 0.783 & 0.459 & 0.815 & -0.042 \\
\hline Chile & $\begin{array}{l}1990- \\
1995\end{array}$ & 0.668 & 0.773 & 0.575 & 0.756 & 1.08 & 1.363 & 0.856 & 1.126 & 1.106 & -0.020 \\
\hline Chile & $\begin{array}{l}1995- \\
2000\end{array}$ & 0.952 & 0.966 & 0.962 & 0.748 & 1.5 & 1.411 & 1.377 & 1.071 & 1.34 & -0.002 \\
\hline Colombia & $\begin{array}{l}1990- \\
1995\end{array}$ & 0.778 & 0.643 & 0.302 & 0.451 & 2.23 & 1.09 & 0.719 & 1.075 & 1.278 & -0.006 \\
\hline Costa Rica & $\begin{array}{l}1985- \\
1990 \\
\end{array}$ & 0.956 & 0.531 & 0.917 & 0.524 & 0.757 & 0.568 & 1.145 & 0.655 & 0.781 & -0.045 \\
\hline Costa Rica & $\begin{array}{l}1990- \\
1995\end{array}$ & 0.892 & 0.575 & 0.698 & 0.832 & 0.751 & 0.743 & 1.001 & 1.193 & 0.922 & -0.034 \\
\hline
\end{tabular}




\begin{tabular}{|c|c|c|c|c|c|c|c|c|c|c|c|}
\hline Costa Rica & $\begin{array}{l}1995- \\
2000\end{array}$ & 0.959 & 0.563 & 0.868 & 0.672 & 0.892 & 0.613 & 1.216 & 0.941 & 0.915 & -0.035 \\
\hline Cyprus & $\begin{array}{l}1980- \\
1985\end{array}$ & 0.805 & 1.116 & 1.248 & 1.251 & 0.565 & 1.481 & 1.326 & 1.328 & 1.175 & -0.014 \\
\hline Cyprus & $\begin{array}{l}1985- \\
1990\end{array}$ & 0.832 & 1.182 & 1.247 & 1.306 & 0.663 & 1.472 & 1.289 & 1.35 & 1.193 & -0.013 \\
\hline Cyprus & $\begin{array}{l}1990- \\
1995\end{array}$ & 1.113 & 1.204 & 1.139 & 1.845 & 0.897 & 1.438 & 1.084 & 1.757 & 1.294 & -0.005 \\
\hline Cyprus & $\begin{array}{l}1995- \\
2000\end{array}$ & 1.19 & 1.002 & 1.491 & 1.619 & 0.941 & 0.977 & 1.314 & 1.427 & 1.165 & -0.015 \\
\hline Czech Rep. & $\begin{array}{l}1990- \\
1995\end{array}$ & 0.89 & 1.228 & 0.995 & 1.244 & 1.043 & 1.148 & 0.827 & 1.033 & 1.013 & -0.027 \\
\hline Czech Rep. & $\begin{array}{l}1995- \\
2000\end{array}$ & 0.952 & 1.089 & 1.086 & 0.777 & 1.806 & 1.119 & 0.954 & 0.683 & 1.14 & -0.017 \\
\hline Denmark & $\begin{array}{l}1980- \\
1985\end{array}$ & 1.384 & 1.179 & 0.952 & 0.705 & 1.579 & 0.829 & 0.758 & 0.562 & 0.932 & -0.033 \\
\hline Denmark & $\begin{array}{l}1985- \\
1990\end{array}$ & 1.429 & 1.291 & 1.073 & 0.756 & 1.755 & 0.839 & 0.88 & 0.62 & 1.023 & -0.026 \\
\hline Denmark & $\begin{array}{l}1990- \\
1995\end{array}$ & 1.336 & 1.236 & 1.093 & 1.791 & 1.58 & 0.77 & 0.837 & 1.371 & 1.139 & -0.017 \\
\hline Denmark & $\begin{array}{l}1995- \\
2000\end{array}$ & 1.428 & 1.23 & 1.62 & 1.234 & 1.801 & 0.758 & 1.31 & 0.998 & 1.217 & -0.011 \\
\hline $\begin{array}{l}\text { Dominican } \\
\text { Rep. }\end{array}$ & $\begin{array}{l}1990- \\
1995\end{array}$ & 0.668 & 0.405 & 0.239 & 0.29 & 1.302 & 1.169 & 0.528 & 0.639 & 0.909 & -0.035 \\
\hline $\begin{array}{l}\text { Dominican } \\
\text { Rep. }\end{array}$ & $\begin{array}{l}1995- \\
2000\end{array}$ & 0.836 & 0.725 & 0.32 & 0.397 & 1.172 & 1.783 & 0.616 & 0.764 & 1.084 & -0.021 \\
\hline Egypt & $\begin{array}{l}1990- \\
1995\end{array}$ & 0.757 & 0.919 & 0.8 & 0.521 & 0.61 & 1.011 & 0.723 & 0.471 & 0.704 & -0.051 \\
\hline Egypt & $\begin{array}{l}1995- \\
2000\end{array}$ & 0.592 & 0.927 & 0.701 & 0.563 & 0.465 & 0.978 & 0.677 & 0.543 & 0.666 & -0.054 \\
\hline El Salvador & $\begin{array}{l}1995- \\
2000\end{array}$ & 0.647 & 0.515 & 0.648 & 0.694 & 0.539 & 1.089 & 1.287 & 1.378 & 1.073 & -0.022 \\
\hline Finland & $\begin{array}{l}1985- \\
1990\end{array}$ & 1.429 & 1.383 & 1.257 & 0.868 & 2.288 & 1.186 & 1.318 & 0.911 & 1.426 & 0.005 \\
\hline Finland & $\begin{array}{l}1990- \\
1995\end{array}$ & 1.336 & 1.305 & 1.248 & 1.22 & 1.786 & 0.909 & 0.99 & 0.967 & 1.163 & -0.015 \\
\hline Finland & $\begin{array}{l}1995- \\
2000\end{array}$ & 1.312 & 1.304 & 1.773 & 1.598 & 1.911 & 0.905 & 1.485 & 1.338 & 1.41 & 0.004 \\
\hline France & $\begin{array}{l}1980- \\
1985\end{array}$ & 1.384 & 1.156 & 1.163 & 0.667 & 1.092 & 1.067 & 0.91 & 0.521 & 0.898 & -0.036 \\
\hline France & $\begin{array}{l}1985- \\
1990\end{array}$ & 1.309 & 1.275 & 1.168 & 0.742 & 1.108 & 1.056 & 0.859 & 0.545 & 0.892 & -0.036 \\
\hline France & $\begin{array}{l}1990- \\
1995\end{array}$ & 1.112 & 1.331 & 1.113 & 1.477 & 0.953 & 1.117 & 0.782 & 1.038 & 0.972 & -0.030 \\
\hline France & $\begin{array}{l}1995- \\
2000\end{array}$ & 1.068 & 1.295 & 1.289 & 1.438 & 0.945 & 1.075 & 0.869 & 0.969 & 0.965 & -0.031 \\
\hline Germany & $\begin{array}{l}1990- \\
1995\end{array}$ & 1.336 & 1.255 & 1.592 & 1.33 & 1.356 & 1.272 & 1.588 & 1.326 & 1.386 & 0.002 \\
\hline Germany & $\begin{array}{l}1995- \\
2000\end{array}$ & 1.306 & 1.207 & 1.547 & 1.467 & 1.234 & 1.272 & 1.445 & 1.371 & 1.331 & -0.002 \\
\hline Greece & $\begin{array}{l}1980- \\
1985\end{array}$ & 0.739 & 1.142 & 0.86 & 0.559 & 0.477 & 2.826 & 0.77 & 0.5 & 1.143 & -0.017 \\
\hline Greece & $\begin{array}{l}1985- \\
1990\end{array}$ & 0.98 & 1.229 & 0.875 & 0.41 & 0.555 & 2.431 & 0.64 & 0.3 & 0.981 & -0.029 \\
\hline Greece & $\begin{array}{l}1990- \\
1995\end{array}$ & 1.002 & 1.215 & 0.729 & 0.555 & 0.839 & 2.303 & 0.626 & 0.477 & 1.061 & -0.023 \\
\hline Greece & $\begin{array}{l}1995- \\
2000\end{array}$ & 1.074 & 1.188 & 1.172 & 0.577 & 1.058 & 1.971 & 1.144 & 0.563 & 1.184 & -0.014 \\
\hline
\end{tabular}




\begin{tabular}{|c|c|c|c|c|c|c|c|c|c|c|c|}
\hline Hungary & $\begin{array}{l}1980- \\
1985\end{array}$ & 0.922 & 0.987 & 0.79 & 1.289 & 0.861 & 0.98 & 0.474 & 0.773 & 0.772 & -0.046 \\
\hline Hungary & $\begin{array}{l}1985- \\
1990\end{array}$ & 1.049 & 1.111 & 0.777 & 0.342 & 0.964 & 0.93 & 0.438 & 0.193 & 0.631 & -0.057 \\
\hline Hungary & $\begin{array}{l}1990- \\
1995\end{array}$ & 1.102 & 1.212 & 0.766 & 0.472 & 0.963 & 0.905 & 0.439 & 0.27 & 0.644 & -0.056 \\
\hline Hungary & $\begin{array}{l}1995- \\
2000\end{array}$ & 1.19 & 1.166 & 0.72 & 0.456 & 1.545 & 1.224 & 0.498 & 0.315 & 0.895 & -0.036 \\
\hline Iceland & $\begin{array}{l}1985- \\
1990\end{array}$ & 1.429 & 1.268 & 0.83 & 2.745 & 0.842 & 1.201 & 0.862 & 2.854 & 1.44 & 0.006 \\
\hline Iceland & $\begin{array}{l}\text { 1990- } \\
1995\end{array}$ & 1.336 & 1.228 & 0.904 & 1.258 & 0.787 & 1.117 & 0.858 & 1.193 & 0.989 & -0.029 \\
\hline Iceland & $\begin{array}{l}1995- \\
2000\end{array}$ & 1.428 & 1.174 & 1.228 & 1.638 & 0.881 & 1.003 & 1.238 & 1.652 & 1.193 & -0.013 \\
\hline India & $\begin{array}{l}1995- \\
2000\end{array}$ & 0.83 & 0.534 & 0.779 & 0.324 & 2.335 & 0.87 & 1.602 & 0.667 & 1.369 & 0.001 \\
\hline Indonesia & $\begin{array}{l}1985- \\
1990\end{array}$ & 0.154 & 0.563 & 0.679 & 0.536 & 0.315 & 3.07 & 1.051 & 0.829 & 1.316 & -0.003 \\
\hline Indonesia & $\begin{array}{l}1990- \\
1995\end{array}$ & 0.668 & 0.597 & 0.721 & 0.703 & 1.487 & 2.196 & 1.3 & 1.268 & 1.563 & 0.016 \\
\hline Iran & $\begin{array}{l}1990- \\
1995 \\
\end{array}$ & 0.89 & 1.003 & 0.621 & 0.293 & 0.744 & 1.038 & 0.898 & 0.424 & 0.776 & -0.045 \\
\hline Ireland & $\begin{array}{l}1980- \\
1985\end{array}$ & 1.153 & 1.151 & 0.794 & 0.459 & 1.281 & 0.998 & 0.552 & 0.319 & 0.788 & -0.045 \\
\hline Ireland & $\begin{array}{l}1985- \\
1990\end{array}$ & 1.191 & 1.188 & 0.934 & 0.632 & 1.429 & 0.986 & 0.656 & 0.443 & 0.878 & -0.037 \\
\hline Ireland & $\begin{array}{l}1990- \\
1995 \\
\end{array}$ & 1.224 & 1.219 & 0.803 & 1.335 & 1.597 & 1.11 & 0.639 & 1.062 & 1.102 & -0.020 \\
\hline Ireland & $\begin{array}{l}1995- \\
2000\end{array}$ & 1.183 & 1.058 & 1.013 & 1.083 & 1.878 & 1.079 & 0.905 & 0.968 & 1.207 & -0.012 \\
\hline Israel & $\begin{array}{l}1995- \\
2000\end{array}$ & 1.153 & 1.163 & 1.616 & 0.604 & 0.702 & 0.748 & 1.058 & 0.395 & 0.726 & -0.049 \\
\hline Italy & $\begin{array}{l}1995- \\
2000\end{array}$ & 1.068 & 1.214 & 1.089 & 0.771 & 1.269 & 1.272 & 0.738 & 0.522 & 0.95 & -0.032 \\
\hline Jamaica & $\begin{array}{l}1980- \\
1985\end{array}$ & 0.574 & 0.814 & 0.551 & 0.342 & 0.381 & 0.646 & 0.463 & 0.287 & 0.444 & -0.071 \\
\hline Jamaica & $\begin{array}{l}\text { 1985- } \\
1990\end{array}$ & 0.594 & 0.945 & 0.408 & 0.24 & 0.282 & 0.851 & 0.334 & 0.196 & 0.416 & -0.074 \\
\hline Jamaica & $\begin{array}{l}1990- \\
1995 \\
\end{array}$ & 0.778 & 0.9 & 0.4 & 0.265 & 0.593 & 0.974 & 0.587 & 0.389 & 0.636 & -0.056 \\
\hline Jamaica & $\begin{array}{l}1995- \\
2000 \\
\end{array}$ & 0.83 & 1.085 & 0.819 & 0.309 & 0.451 & 0.905 & 0.721 & 0.272 & 0.587 & -0.060 \\
\hline Japan & $\begin{array}{l}1980- \\
1985\end{array}$ & 1.266 & 1.349 & 1.479 & 1.993 & 5.247 & 1.232 & 2.676 & 3.606 & 3.19 & 0.143 \\
\hline Japan & $\begin{array}{l}1985- \\
1990\end{array}$ & 1.309 & 1.439 & 1.475 & 2.489 & 5.594 & 1.352 & 2.816 & 4.753 & 3.629 & 0.177 \\
\hline Japan & $\begin{array}{l}1990- \\
1995 \\
\end{array}$ & 1.224 & 1.39 & 1.371 & 2.784 & 5.47 & 1.816 & 2.128 & 4.322 & 3.434 & 0.162 \\
\hline Jordan & $\begin{array}{l}\text { 1985- } \\
1990 \\
\end{array}$ & 0.715 & 0.488 & 0.627 & 0.523 & 0.346 & 0.46 & 0.56 & 0.467 & 0.458 & -0.070 \\
\hline Jordan & $\begin{array}{l}\text { 1990- } \\
1995\end{array}$ & 0.89 & 0.584 & 0.85 & 0.859 & 0.455 & 0.368 & 0.807 & 0.816 & 0.611 & -0.058 \\
\hline Jordan & $\begin{array}{l}1995- \\
2000\end{array}$ & 0.952 & 0.818 & 0.992 & 0.682 & 0.465 & 0.551 & 0.956 & 0.657 & 0.658 & -0.055 \\
\hline Korea, Rep & $\begin{array}{l}1980- \\
1985\end{array}$ & 0.687 & 1.191 & 1.193 & 0.811 & 0.89 & 1.54 & 2.266 & 1.539 & 1.559 & 0.016 \\
\hline Korea, Rep & $\begin{array}{l}1985- \\
1990\end{array}$ & 0.711 & 1.275 & 1.263 & 1.152 & 1.131 & 1.542 & 2.542 & 2.319 & 1.883 & 0.041 \\
\hline
\end{tabular}




\begin{tabular}{|c|c|c|c|c|c|c|c|c|c|c|c|}
\hline Korea, Rep & $\begin{array}{l}1990- \\
1995\end{array}$ & 1.113 & 1.353 & 1.176 & 1.645 & 1.96 & 1.653 & 2.225 & 3.112 & 2.237 & 0.069 \\
\hline Korea, Rep & $\begin{array}{l}1995- \\
2000\end{array}$ & 1.068 & 1.333 & 1.512 & 1.165 & 2.254 & 1.757 & 2.753 & 2.121 & 2.221 & 0.067 \\
\hline Lebanon & $\begin{array}{l}1995- \\
2000\end{array}$ & 0.354 & 1.039 & 0.548 & 0.771 & 0.311 & 2.071 & 0.46 & 0.648 & 0.872 & -0.038 \\
\hline Luxembourg & $\begin{array}{l}1980- \\
1985\end{array}$ & 1.372 & 0.936 & 1.136 & 1.704 & 1.418 & 0.8 & 0.867 & 1.3 & 1.096 & -0.020 \\
\hline Luxembourg & $\begin{array}{l}1985- \\
1990\end{array}$ & 1.429 & 0.953 & 1.044 & 2.003 & 1.585 & 0.958 & 0.871 & 1.671 & 1.271 & -0.007 \\
\hline Luxembourg & $\begin{array}{l}1990- \\
1995\end{array}$ & 1.336 & 0.944 & 0.418 & 2.34 & 1.426 & 1.396 & 0.331 & 1.85 & 1.251 & -0.008 \\
\hline Luxembourg & $\begin{array}{l}1995- \\
2000\end{array}$ & 1.342 & 0.929 & 0.299 & 2.274 & 1.441 & 1.12 & 0.238 & 1.81 & 1.152 & -0.016 \\
\hline Malaysia & $\begin{array}{l}1995- \\
2000\end{array}$ & 0.952 & 1.277 & 0.933 & 1.559 & 1.012 & 1.357 & 1.378 & 2.301 & 1.512 & 0.012 \\
\hline Mexico & $\begin{array}{l}1980- \\
1985\end{array}$ & 0.624 & 0.649 & 0.755 & 0.165 & 1.003 & 0.741 & 1.165 & 0.254 & 0.791 & -0.044 \\
\hline Mexico & $\begin{array}{l}1985- \\
1990\end{array}$ & 0.715 & 0.666 & 0.731 & 0.94 & 1.325 & 0.888 & 0.91 & 1.17 & 1.074 & -0.022 \\
\hline Mexico & $\begin{array}{l}1990- \\
1995\end{array}$ & 0.668 & 0.722 & 0.725 & 1.077 & 1.319 & 0.811 & 1.467 & 2.18 & 1.444 & 0.007 \\
\hline Mexico & $\begin{array}{l}1995- \\
2000\end{array}$ & 0.592 & 0.771 & 0.726 & 0.964 & 1.51 & 0.764 & 1.455 & 1.931 & 1.415 & 0.004 \\
\hline Namibia & $\begin{array}{l}1990- \\
1995\end{array}$ & 1.113 & 0.504 & 1.128 & 0.403 & 0.417 & 0.269 & 0.991 & 0.354 & 0.508 & -0.066 \\
\hline Namibia & $\begin{array}{l}1995- \\
2000\end{array}$ & 1.068 & 0.432 & 1.115 & 0.343 & 0.425 & 0.254 & 0.959 & 0.295 & 0.483 & -0.068 \\
\hline Netherlands & $\begin{array}{l}1980- \\
1985\end{array}$ & 1.384 & 1.254 & 1.501 & 1.114 & 1.65 & 0.907 & 0.912 & 0.677 & 1.037 & -0.025 \\
\hline Netherlands & $\begin{array}{l}1985- \\
1990\end{array}$ & 1.429 & 1.243 & 1.47 & 2.888 & 1.762 & 0.901 & 0.873 & 1.714 & 1.313 & -0.004 \\
\hline Netherlands & $\begin{array}{l}1990- \\
1995\end{array}$ & 1.336 & 1.279 & 1.291 & 1.528 & 1.744 & 1.115 & 0.799 & 0.945 & 1.15 & -0.016 \\
\hline Netherlands & $\begin{array}{l}1995- \\
2000\end{array}$ & 1.428 & 1.273 & 1.561 & 1.312 & 1.947 & 1.271 & 1.037 & 0.871 & 1.281 & -0.006 \\
\hline New Zealand & $\begin{array}{l}1980- \\
1985\end{array}$ & 1.384 & 1.185 & 0.86 & 0.744 & 1.235 & 1.165 & 0.7 & 0.605 & 0.926 & -0.034 \\
\hline New Zealand & $\begin{array}{l}1985- \\
1990\end{array}$ & 1.429 & 1.264 & 0.924 & 0.599 & 1.269 & 1.042 & 0.684 & 0.443 & 0.86 & -0.039 \\
\hline New Zealand & $\begin{array}{l}1990- \\
1995\end{array}$ & 1.336 & 1.256 & 0.875 & 1.583 & 0.893 & 0.885 & 0.704 & 1.273 & 0.939 & -0.033 \\
\hline New Zealand & $\begin{array}{l}1995- \\
2000\end{array}$ & 1.306 & 1.241 & 0.71 & 1.355 & 0.784 & 0.872 & 0.677 & 1.293 & 0.907 & -0.035 \\
\hline Nicaragua & $\begin{array}{l}1995- \\
2000\end{array}$ & 0.721 & 0.449 & 0.315 & 0.355 & 0.588 & 0.626 & 0.271 & 0.305 & 0.447 & -0.071 \\
\hline Norway & $\begin{array}{l}1980- \\
1985\end{array}$ & 1.293 & 1.217 & 0.978 & 1.207 & 1.716 & 0.993 & 0.92 & 1.135 & 1.191 & -0.013 \\
\hline Norway & $\begin{array}{l}1985- \\
1990\end{array}$ & 1.312 & 1.304 & 1.017 & 1.06 & 1.763 & 0.916 & 0.853 & 0.889 & 1.105 & -0.020 \\
\hline Norway & $\begin{array}{l}1990- \\
1995\end{array}$ & 1.336 & 1.346 & 0.998 & 1.649 & 1.537 & 0.833 & 0.738 & 1.221 & 1.082 & -0.022 \\
\hline Norway & $\begin{array}{l}1995- \\
2000\end{array}$ & 1.306 & 1.325 & 1.129 & 1.488 & 1.698 & 0.849 & 0.949 & 1.251 & 1.187 & -0.013 \\
\hline Panama & $\begin{array}{l}1980- \\
1985\end{array}$ & 0.348 & 0.677 & 0.525 & 1.003 & 0.205 & 0.787 & 0.541 & 1.034 & 0.642 & -0.056 \\
\hline Panama & $\begin{array}{l}1985- \\
1990\end{array}$ & 0.359 & 0.754 & 0.363 & 3.949 & 0.209 & 0.712 & 0.419 & 4.555 & 1.474 & 0.009 \\
\hline
\end{tabular}




\begin{tabular}{|c|c|c|c|c|c|c|c|c|c|c|c|}
\hline Paraguay & $\begin{array}{l}1985- \\
1990\end{array}$ & 0.117 & 0.384 & 3.504 & 0.489 & 0.228 & 1.539 & 12.52 & 1.747 & 4.008 & - \\
\hline Paraguay & $\begin{array}{l}1990- \\
1995\end{array}$ & 0.556 & 0.503 & 10.84 & 0.698 & 0.822 & 1.043 & 28.17 & 1.812 & 7.96 & - \\
\hline Peru & $\begin{array}{l}1980- \\
1985\end{array}$ & 0.579 & 0.693 & 0.717 & 0.11 & 0.633 & 1.202 & 1.252 & 0.192 & 0.82 & -0.042 \\
\hline Peru & $\begin{array}{l}1990- \\
1995\end{array}$ & 0.557 & 0.749 & 0.356 & 0.356 & 0.97 & 1.137 & 0.603 & 0.603 & 0.828 & -0.041 \\
\hline Peru & $\begin{array}{l}1995- \\
2000\end{array}$ & 0.598 & 0.845 & 0.587 & 0.606 & 0.84 & 1.317 & 0.993 & 1.025 & 1.044 & -0.025 \\
\hline Philippines & $\begin{array}{l}1980- \\
1985\end{array}$ & 0.192 & 0.701 & 1.417 & 0.604 & 0.259 & 1.952 & 3.714 & 1.583 & 1.877 & 0.040 \\
\hline Philippines & $\begin{array}{l}1985- \\
1990\end{array}$ & 0.359 & 0.842 & 0.449 & 0.485 & 0.467 & 1.768 & 0.946 & 1.021 & 1.05 & -0.024 \\
\hline Philippines & $\begin{array}{l}1990- \\
1995\end{array}$ & 0.557 & 0.829 & 0.449 & 0.622 & 0.649 & 1.459 & 0.733 & 1.015 & 0.964 & -0.031 \\
\hline Poland & $\begin{array}{l}1990- \\
1995\end{array}$ & 1.058 & 1.191 & 0.731 & 0.271 & 0.93 & 1.127 & 0.547 & 0.203 & 0.702 & -0.051 \\
\hline Portugal & $\begin{array}{l}1985- \\
1990\end{array}$ & 0.98 & 1.038 & 0.84 & 0.472 & 0.825 & 1.246 & 0.709 & 0.398 & 0.794 & -0.044 \\
\hline Portugal & $\begin{array}{l}1990- \\
1995\end{array}$ & 0.946 & 1.095 & 0.849 & 0.926 & 0.577 & 1.058 & 0.643 & 0.701 & 0.744 & -0.048 \\
\hline Portugal & $\begin{array}{l}1995- \\
2000\end{array}$ & 1.074 & 1.205 & 1.015 & 1.033 & 0.661 & 1.094 & 0.797 & 0.811 & 0.841 & -0.040 \\
\hline Romania & $\begin{array}{l}1990- \\
1995\end{array}$ & 0.669 & 1.029 & 0.736 & 0.419 & 0.58 & 1.495 & 0.663 & 0.377 & 0.779 & -0.045 \\
\hline Romania & $\begin{array}{l}1995- \\
2000\end{array}$ & 0.598 & 1.038 & 0.845 & 0.512 & 0.546 & 1.282 & 0.805 & 0.487 & 0.78 & -0.045 \\
\hline South Africa & $\begin{array}{l}1985- \\
1990\end{array}$ & 1.309 & 0.751 & 1.302 & 0.234 & 0.805 & 0.626 & 1.361 & 0.244 & 0.759 & -0.047 \\
\hline South Africa & $\begin{array}{l}1990- \\
1995\end{array}$ & 1.069 & 0.812 & 1.02 & 0.403 & 0.673 & 0.615 & 1.015 & 0.401 & 0.676 & -0.053 \\
\hline South Africa & $\begin{array}{l}1995- \\
2000\end{array}$ & 1.074 & 0.768 & 1.17 & 0.352 & 1.381 & 0.605 & 1.186 & 0.357 & 0.882 & -0.037 \\
\hline Spain & $\begin{array}{l}1995- \\
2000\end{array}$ & 1.19 & 1.259 & 1.02 & 0.667 & 2.132 & 1.337 & 0.929 & 0.607 & 1.251 & -0.008 \\
\hline Sweden & $\begin{array}{l}1985- \\
1990\end{array}$ & 1.429 & 1.267 & 1.105 & 1.299 & 2.461 & 0.824 & 0.863 & 1.015 & 1.291 & -0.005 \\
\hline Sweden & $\begin{array}{l}1990- \\
1995\end{array}$ & 1.336 & 1.388 & 0.99 & 1.031 & 1.979 & 0.869 & 0.694 & 0.723 & 1.066 & -0.023 \\
\hline Sweden & $\begin{array}{l}1995- \\
2000\end{array}$ & 1.428 & 1.368 & 1.234 & 2.248 & 2.129 & 0.877 & 0.894 & 1.628 & 1.382 & 0.002 \\
\hline Switzerland & $\begin{array}{l}1980- \\
1985\end{array}$ & 1.384 & 1.119 & 1.239 & 4.532 & 2.379 & 1.128 & 2.089 & 7.642 & 3.31 & 0.152 \\
\hline Switzerland & $\begin{array}{l}1990- \\
1995\end{array}$ & 1.336 & 1.178 & 1.099 & 1.95 & 1.672 & 1.009 & 1.346 & 2.389 & 1.604 & 0.019 \\
\hline Switzerland & $\begin{array}{l}1995- \\
2000\end{array}$ & 1.306 & 1.142 & 1.41 & 2.735 & 1.575 & 1.006 & 1.59 & 3.083 & 1.813 & 0.035 \\
\hline Syria & $\begin{array}{l}1980- \\
1985\end{array}$ & 0.461 & 0.72 & 0.767 & 0.8 & 0.224 & 0.642 & 0.577 & 0.602 & 0.511 & -0.066 \\
\hline Thailand & $\begin{array}{l}1995- \\
2000\end{array}$ & 0.83 & 0.759 & 0.999 & 2.025 & 0.849 & 0.837 & 1.551 & 3.145 & 1.596 & 0.018 \\
\hline $\begin{array}{l}\text { Trinidad \& } \\
\text { Tobago }\end{array}$ & $\begin{array}{l}1990- \\
1995\end{array}$ & 0.668 & 0.917 & 0.631 & 0.525 & 0.431 & 1.138 & 0.7 & 0.583 & 0.713 & -0.050 \\
\hline $\begin{array}{l}\text { Trinidad \& } \\
\text { Tobago }\end{array}$ & $\begin{array}{l}1995- \\
2000\end{array}$ & 0.714 & 0.996 & 0.984 & 0.557 & 0.488 & 1.51 & 1.089 & 0.616 & 0.926 & -0.034 \\
\hline Tunisia & $\begin{array}{l}1985- \\
1990\end{array}$ & 0.715 & 0.632 & 0.647 & 0.502 & 0.567 & 0.498 & 0.567 & 0.441 & 0.518 & -0.066 \\
\hline
\end{tabular}




\begin{tabular}{|c|c|c|c|c|c|c|c|c|c|c|c|}
\hline Tunisia & $\begin{array}{l}1995- \\
2000\end{array}$ & 0.714 & 0.754 & 0.863 & 0.739 & 0.551 & 0.536 & 0.836 & 0.716 & 0.66 & -0.055 \\
\hline Turkey & $\begin{array}{l}1980- \\
1985\end{array}$ & 0.692 & 0.51 & 0.728 & 0.258 & 0.798 & 1.076 & 1.169 & 0.413 & 0.864 & -0.039 \\
\hline Turkey & $\begin{array}{l}1985- \\
1990\end{array}$ & 0.594 & 0.615 & 0.731 & 0.28 & 0.877 & 1.895 & 1.327 & 0.509 & 1.152 & -0.016 \\
\hline Turkey & $\begin{array}{l}1990- \\
1995\end{array}$ & 0.846 & 0.723 & 0.728 & 0.419 & 0.772 & 1.201 & 1.058 & 0.609 & 0.91 & -0.035 \\
\hline Turkey & $\begin{array}{l}1995- \\
2000\end{array}$ & 0.707 & 0.705 & 0.705 & 0.518 & 0.702 & 1.544 & 0.736 & 0.541 & 0.881 & -0.037 \\
\hline $\begin{array}{l}\text { United } \\
\text { Kingdom }\end{array}$ & $\begin{array}{l}1980- \\
1985\end{array}$ & 1.384 & 1.132 & 0.963 & 0.673 & 1.074 & 1.06 & 0.782 & 0.547 & 0.866 & -0.038 \\
\hline $\begin{array}{l}\text { United } \\
\text { Kingdom }\end{array}$ & $\begin{array}{l}1985- \\
1990\end{array}$ & 1.309 & 1.175 & 0.936 & 0.582 & 1.117 & 1.093 & 0.798 & 0.497 & 0.876 & -0.038 \\
\hline $\begin{array}{l}\text { United } \\
\text { Kingdom }\end{array}$ & $\begin{array}{l}1990- \\
1995\end{array}$ & 1.224 & 1.29 & 0.894 & 0.991 & 0.995 & 1.17 & 0.677 & 0.751 & 0.898 & -0.036 \\
\hline $\begin{array}{l}\text { United } \\
\text { Kingdom }\end{array}$ & $\begin{array}{l}1995- \\
2000\end{array}$ & 1.232 & 1.288 & 1.048 & 0.975 & 1.09 & 1.278 & 0.844 & 0.785 & 0.999 & -0.028 \\
\hline Uruguay & $\begin{array}{l}1995- \\
2000\end{array}$ & 0.83 & 0.901 & 0.472 & 0.382 & 0.89 & 1.662 & 0.484 & 0.392 & 0.857 & 0.001 \\
\hline USA & $\begin{array}{l}1980- \\
1985\end{array}$ & 1.266 & 1.291 & 1.044 & 0.851 & 1.778 & 1.001 & 1.494 & 1.218 & 1.373 & 0.006 \\
\hline USA & $\begin{array}{l}1985- \\
1990 \\
\end{array}$ & 1.309 & 1.275 & 1.161 & 0.878 & 1.821 & 1.093 & 1.612 & 1.219 & 1.436 & 0.014 \\
\hline USA & $\begin{array}{l}1990- \\
1995\end{array}$ & 1.224 & 1.268 & 0.962 & 1.287 & 1.955 & 1.154 & 1.307 & 1.748 & 1.541 & 0.045 \\
\hline USA & $\begin{array}{l}1995- \\
2000\end{array}$ & 1.183 & 1.24 & 1.288 & 1.282 & 2.637 & 1.218 & 1.954 & 1.944 & 1.938 & -0.039 \\
\hline Venezuela & $\begin{array}{l}1980- \\
1985\end{array}$ & 0.692 & 0.224 & 0.617 & 0.585 & 0.684 & 0.213 & 0.92 & 0.872 & 0.672 & -0.054 \\
\hline Venezuela & $\begin{array}{l}1985- \\
1990\end{array}$ & 0.715 & 0.276 & 0.462 & 0.283 & 0.996 & 0.265 & 0.72 & 0.44 & 0.606 & -0.059 \\
\hline Venezuela & $\begin{array}{l}1990- \\
1995\end{array}$ & 0.668 & 0.271 & 0.341 & 0.424 & 1.042 & 0.287 & 0.539 & 0.669 & 0.634 & -0.057 \\
\hline Venezuela & $\begin{array}{l}1995- \\
2000\end{array}$ & 0.714 & 0.307 & 0.603 & 0.305 & 1.534 & 0.302 & 0.978 & 0.494 & 0.827 & -0.041 \\
\hline Yemen & $\begin{array}{l}1995- \\
2000\end{array}$ & 0.714 & 0.484 & 0.332 & 0.115 & 0.479 & 0.446 & 0.351 & 0.122 & 0.35 & -0.079 \\
\hline
\end{tabular}

Key:

PSP: Public Sector Performance

PSE: Public Sector Efficiency

Admin: Administration

Educ: Education

Infrast: Infrastructure

Stabil: Stabilization

* See footnote 6 
Table A.2: Technical Efficiency (TE) of public spending in 52 countries, 1995-2000

\begin{tabular}{|l|l|l|l|l|l|}
\hline Country & TE & $\begin{array}{c}\text { Growth } \\
\text { effect }\end{array}$ & Country & TE & $\begin{array}{c}\text { Growth } \\
\text { effect }\end{array}$ \\
\hline Algeria & 0.363355 & -0.133 & New Zealand & 0.7823 & -0.027 \\
\hline Argentina (see fn 6) & 0.830471 & - & Nicaragua & 0.312448 & -0.146 \\
\hline Australia & 0.875214 & -0.004 & Norway & 0.858392 & -0.008 \\
\hline Austria & 0.867984 & -0.005 & Peru & 0.509566 & -0.096 \\
\hline Bulgaria & 0.466058 & -0.107 & Portugal & 0.706914 & -0.046 \\
\hline Canada & 0.910333 & 0.005 & Romania & 0.513156 & -0.095 \\
\hline Chile & 0.672651 & -0.055 & South Africa & 0.582557 & -0.078 \\
\hline Costa Rica & 0.56748 & -0.081 & Spain & 0.697047 & -0.049 \\
\hline Cyprus & 0.872052 & -0.004 & Sweden & 0.934942 & 0.012 \\
\hline Czech Republic & 0.653997 & -0.060 & Switzerland & 0.965281 & 0.019 \\
\hline Denmark & 0.885186 & -0.001 & Thailand & 0.857647 & -0.008 \\
\hline Dominican Rep. & 0.453656 & -0.110 & Trinidad \& Tobago & 0.573398 & -0.080 \\
\hline Egypt & 0.47918 & -0.104 & Tunisia & 0.527729 & -0.091 \\
\hline El Salvador & 0.500757 & -0.098 & Turkey & 0.461675 & -0.108 \\
\hline Finland & 0.928959 & 0.010 & United Kingdom & 0.745181 & -0.036 \\
\hline France & 0.802157 & -0.022 & Uruguay & 0.451386 & 0.004 \\
\hline Germany & 0.903573 & 0.004 & USA & 0.903279 & -0.111 \\
\hline Greece & 0.686213 & -0.051 & Venezuela & 0.372336 & -0.131 \\
\hline Hungary & 0.565051 & -0.082 & Yemen & 0.292314 & -0.151 \\
\hline Iceland & 0.906244 & 0.004 & & & \\
\hline India & 0.496827 & -0.099 & & & \\
\hline Ireland & 0.727425 & -0.041 & & & \\
\hline Israel & 0.713245 & -0.045 & & & \\
\hline Italy & 0.657281 & -0.059 & & & \\
\hline Jamaica & 0.513118 & -0.095 & & & \\
\hline Jordan & 0.589832 & -0.076 & & & \\
\hline Korea, Rep & 0.927815 & 0.010 & & & \\
\hline Lebanon & 0.454145 & -0.110 & & & \\
\hline Luxembourg & 0.791004 & -0.025 & & & \\
\hline Malaysia & 0.866256 & -0.006 & & & \\
\hline Mexico & 0.608441 & -0.071 & & & \\
\hline Namibia & 0.496673 & -0.099 & & & \\
\hline Netherlands & 0.866055 & -0.006 & & & \\
\hline & & & & \\
\hline
\end{tabular}




\section{References}

Afonso A., L. Schuknecht and V. Tanzi (2005): Public sector efficiency: An international comparison, Public Choice, 123, 321-347.

Afonso A., L. Schuknecht and V. Tanzi (2006): Public sector efficiency: Evidence for new EU member states and emerging markets, ECB Working Paper, no. 581.

Agell J., H. Ohlsson and P. S. Thoursie (2006): Growth effects of government expenditure and taxation in rich countries: A comment, European Economic Review, 50, 211-218.

Anderson T.W. (1984): Introduction to Multivariate Statistical Analysis, 2d edition, New York: John Wiley \& Sons.

Angelopoulos K., G. Economides and P. Kammas (2007): Tax-spending policies and economic growth: Theoretical predictions and evidence from the OECD, European Journal of Political Economy, 23, 885-902.

Angelopoulos K. and A. Philippopoulos (2007): The growth effects of fiscal policy in Greece 19602000, Public Choice, 131, 157-175.

Baum C. F., M. E. Schaffer and S. Stillman (2006): Stata module to Extended instrumental variables/2SLS, GMM and AC/HAC, LIML and k-class regression, http://ideas.repec.org/c/boc/bocode/s425401.html

Barro R. (1990): Government spending in a simple model of economic growth, Journal of Political Economy, 98, S103-S125.

Barro R. and X. Sala-i-Martin (2004): Economic Growth, Second edition, The MIT Press, Cambridge, Mass.

Cragg J.G. and S.G. Donald (1993): Testing identfiability and specification in instrumental variables models, Econometric Theory, 9, 222-240.

De Haan J., S. Lundstrom and J.-E. Sturm (2006): Market-oriented institutions and policies and economic growth: a critical survey, Journal of Economic Surveys, 20, 157-191.

Devarajan S., Swaroop, V., Zoo H. (1996): The composition of public expenditure and economic growth, Journal of Monetary Economics, 37, 313-344.

Dutt P. and D. Mitra (2002): Endogenous trade policy through majority voting: An empirical investigation, Journal of International Economics, 58, 107-133.

Folster S. and M. Henrekson (2001): Growth effects of government expenditure and taxation in rich countries, European Economic Review, 45, 1501-20.

Gemmel N. and R. Kneller (2001): The impact of fiscal policy on long-run growth, European Economy, 1, 98-129.

Greene W. H. (2005): Efficiency of public spending in developing countries: A stochastic frontier approach, May 2005, mimeo. 
Gwartney J., R. Holcombe and R. Lawson (1998): The scope of government and the wealth of nations, Cato Journal, 18, 163-190.

Heston A., R. Summers and B. Aten (2002): Penn World Table Version 6.1, Center for International Comparisons at the University of Pennsylvania (CICUP).

Hillman A. (2003): Public Finance and Public Policy: Responsibilities and Limitations of Government, Cambridge University Press, Cambridge.

Kneller R., M. Bleaney and N. Gemmel (1999): Public policy and the government budget constraint, Journal of Public Economics, 74, 171-190.

Kumbhakar S. C. and C. A. K. Lovell (2000): Stochastic Frontier Analysis, Cambridge University Press, Cambridge

Levine R. and D. Renelt (1992): A sensitivity analysis of cross-country growth regressions, American Economic Review, 82, 942-63.

Miller S. and F. Russek (1997): Fiscal structures and economic growth: international evidence, Economic Inquiry, XXXV, 603-613.

Mueller D. (2003): Public Choice III, Cambridge University Press, Cambridge.

Persson T. and G. Tabellini (2003): The Economic Effects of Constitutions. The MIT Press, Cambridge, Mass.

Tanzi V. and H. R. Davoodi (1998): Corruption, public investment and growth, in The Welfare State, Public Investment and Growth, edited by H. Shibata and T. Ihori, Springer-Verlag, Tokyo.

Tanzi V. and L. Schuknecht (2000): Public Spending in the 20th Century: A Global Perspective, Cambridge University Press, Cambridge.

Tanzi V. and H. Zee (1997): Fiscal policy and long-run growth, IMF Staff Papers, 44, 179-209.

Wooldridge J. W. (2002): Econometric Analysis of Cross Section and Panel Data, The MIT Press, Cambridge, Mass. 